\title{
Current strategies in diagnostics and therapeutics against novel coronavirus disease (COVID-19)
}

FAISAL ALOTAIBI

Department of Pharmacy Practice College of Pharmacy

Shaqra University, KSA
Accepted March 31, 2021

Published online April 1, 2021

The epidemic of COVID-19 spread quickly through China and engulfed all of the countries across the globe. Several advances have been made in understanding the novel coronavirus's pathophysiology and in the development of newer diagnostics with pinpoint accuracy. Several newer therapeutic methods have either been accepted or are awaiting acceptance. In many countries, vaccination programs have been rolled out. Despite all these efforts, coronavirus still exists, though with lesser propensity. Multiple new forms of the novel coronavirus unexpectedly appeared in various areas of the world, undermining previously existing diagnosis and care protocols. This article highlights our understanding of the novel coronavirus's symptoms in brief, pathogenesis, diagnostics, and therapeutic strategies to contain COVID-19. The clinical findings, including serological, radiological, and other advanced diagnostic strategies, contributed much to control the disease. To date, supportive interventions have been used in tandem with potent antiviral therapies such as remdesivir, lopinavir/ ritonavir, or corticosteroids with a level of trust in the care of COVID-19 patients. However, in several areas of the world, vaccination initiatives took place; the vaccines' safety and efficacy to control the outbreak is yet to be identified. This review concludes that improvement in therapies and diagnostics for COVID-19 must continually be explored as new variants constantly emerge.

Keywords: coronavirus disease 2019, COVID-19, SARS-CoV-2, pathogenesis, remdesivir; treatment options

\section{INTRODUCTION}

More than a year ago, a new form of beta coronavirus appeared in Wuhan Area, China, and spread like a bush fire around the globe (1). None of the country on earth was spared from the devastation of the disease. The human sufferings are unaccountable due to the complete breakdown of the economy and healthcare system.

\footnotetext{
*Correspondence; e-mail: f.alshaibani@su.edu.sa; f.alotaibi@hotmail.com
} 
The strain was a different form of the coronavirus, and the people did have little to no understanding of the virus. Everything about the virus was unknown to health care workers: the sign and symptoms of the novel coronavirus disease, the mode of transmission, the pathogenesis (2). In the beginning, the whole world lacked adequate facilities to diagnose this unique virus, and for the countries, there was no other option but to cut off the human to human contact and proximity. A complete lockout has been placed into effect in nearly every area of the world. One year has passed on, the virus still exists, the shock and despair might have diminished, but the virus's after-effects are seen everywhere. As of the $24^{\text {th }}$ of March 2021, more than 123 million people got infected, and almost 3 million people lost their lives (3).

Coronaviruses (CoVs) are made up of single-stranded RNA and belong to the Coronaviridae group, which infect a number of hosts and cause pathological changes from the common cold to severe/fatal respiratory diseases (4). Up until early January 2021, neither active immunity in the form of vaccines nor potent antiviral medications were available for the treatment of human coronavirus infections. The health care agencies were not having any other options but to follow WHO guidelines; the social distancing and quarantining of patients suspected or confirmed for COVID-19. Remdesivir, lopinavir/ritonavir alone or in conjunction with interferon- $\beta$, convalescent plasma, and monoclonal antibodies (mAbs) are the main therapeutic choices used to treat COVID-19 patients (5).

At the beginning of 2021, except in the USA, the novel coronavirus's transmission started declining; the reasons were not clear; the scientist speculated about herd immunity. For almost one year, the world put its entire effort to develop strategies to contain the virus. Most diagnostic techniques have been developed and introduced to the diagnosis of novel coronavirus. Many countries rolled out their vaccines; some were well evaluated and followed the clinical trial guidelines, data of some vaccines were never published. Despite the discrepancies in their results, those vaccines were employed for human use.

Now we have advanced to our approaches in diagnosing and treating this novel coronavirus with a high degree of certainty. Multiple new forms of the novel coronavirus unexpectedly appeared in various areas of the world, undermining previously existing diagnosis and care protocols. These newer variants, the new UK coronavirus type B117 and the South African form (501Y.V2), presented a larger threat to the structures currently in place to manage the virus (6). Will the war footing works across the globe prove futile if these novel mutated strains evade all the recently designed strategies? The question remains unanswered.

This article highlights our latest understanding of the novel coronavirus's symptoms in brief, pathogenesis, diagnostics, and therapeutic strategies to contain COVID-19. These facts and figures may generate some novel ideas which will play a role in getting rid of this deadly coronavirus disease.

\section{SYMPTOMS}

The warning sign of COVID-19 infection generally appears after an average of 5.2 days of infections (5). In the case of a deathly outcome, the documented duration between the beginning of COVID-19 symptoms and death is 6 and 41 days, with an average value of 14 days (7). This period is based on the patient's age and immunity level. Fever, cough, and 


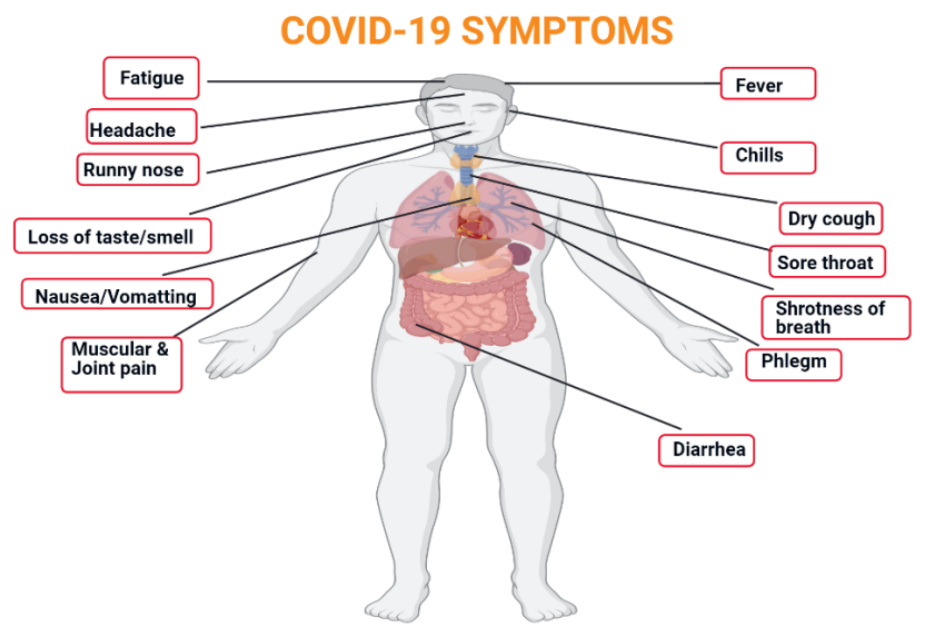

Created in BioRender.com bio

Fig. 1. The virus appears to start with fever accompanied by dry cough and then leads to breathing difficulties after a week and some patients need hospital admission.

weakness or myalgia are the most frequent indications at the start of COVID-19 (Fig. 1), although other symptoms include sputum development, fever, blood-stained bronchial mucus, diarrhea, trouble breathing and loss of smell and taste (8-11).

Novel SARS-CoV-2 virus and older beta coronaviruses worsen effects such as headache, dry cough, and shortness of breath. However, novel SARS-CoV-2 displayed some exclusive clinical features that comprise infecting the lower respiratory tract soon after the upper respiratory tract symptoms like runny nose, sneezing, and sore throat appear (12). Few patients affected by SARS-CoV-2 had digestive issues such as diarrhoea, however, a small percentage of patients reported similar GI discomfort.

\section{PATHOGENESIS AND DIAGNOSIS: CLINICAL MANIFESTATION}

A significant number of documented clinical and literature reports offered ample knowledge regarding the pathogenesis process of novel SARS-CoV-2 infection. The virus reaches to lungs, infecting all around the respiratory tract, primarily the mucous membrane of the larynx and nasal cavity. The virus then reaches the supply of peripheral blood from the lungs and then targets the targeting organs expressing ACE2, such as the lungs, the heart, the gastrointestinal tract, the renal system, etc. $(13,14)$. According to new studies, three elements are involved in the entry of novel SARS-CoV-2: the ACE2 receptor, the neuropilin-1 (NRP1) receptor, and the transmembrane protease serine 2 (TMPRSS2) receptor (15). NRP1 and TMPRSS2 serve as co-receptors to allow SARS-CoV-2 to enter the cells and to cause the viral infection. The olfactory epithelium of humans who died from COVID-19 infection has indicated that the novel coronavirus targets more neuropilin-1(NRP1)-producing cells in the nasal cavity. This may be the basis to assume that the loss of smell is 
due to the excessive viral entry and infectivity of the olfactory epithelial cells. SARS-CoV-2 was detected in stool most likely that it travels from the lungs through the bloodstream and then from the bloodstream to the gastrointestinal tract (16).

In SARS-CoV-2-infected patients, numerous biochemical changes have been observed. Many biomarkers have been discovered to be a significant parameter for verifying infection with SARS-CoV-2, and those biomarkers suggest the magnitude of the disease. Table I highlights alterations of some biomarkers.

COVID-19 infection is investigated using a range of approaches, including molecular, serological, radiological, and microbiological processes. In molecular diagnosis, detection of the virus is done by viral nucleic acid or RNA sequence amplification utilizing the reverse transcriptase-polymerase chain reaction (RT-PCR) technique (30). When using serological diagnosis, a laboratory can screen for antibodies in patients that have novel coronavirus disease, whereas point-of-care or radiology-based diagnoses rely on the existence of clinical changes in patients that may have or are believed to have novel coronavirus disease $(31,32)$. Microbiological methods, especially the diagnosis via viral culture, rely on SARS-CoV-2 separation on cell lines enhancing virus growth and replication (33).

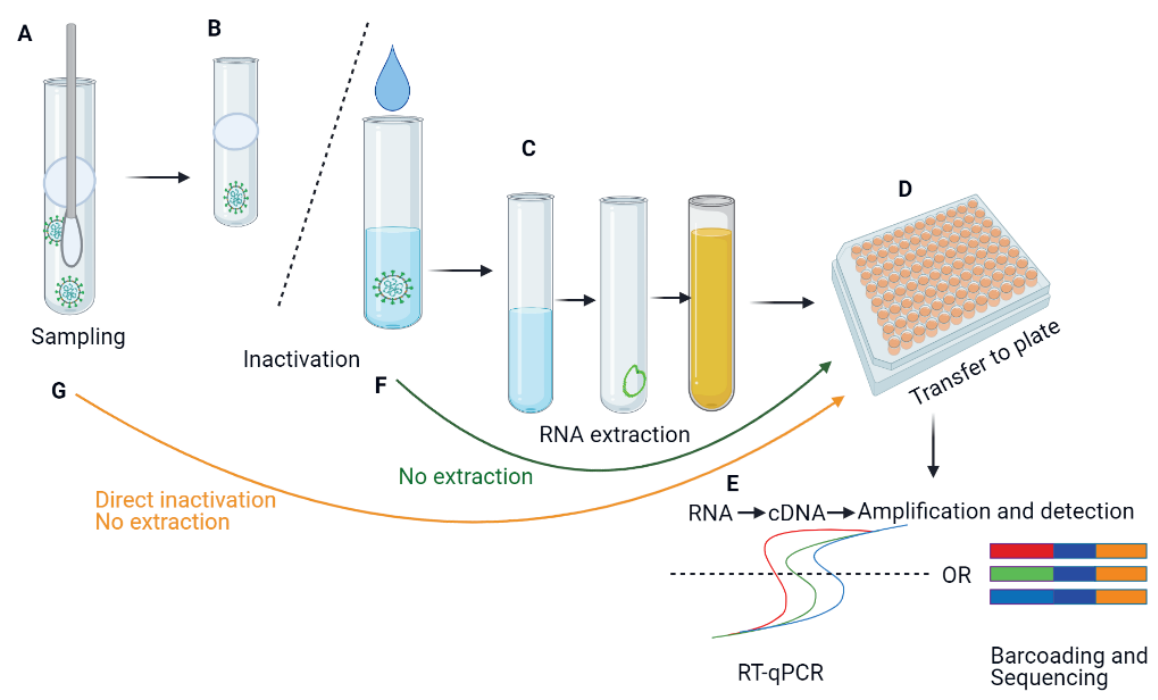

Created in BioRender.com bio

Fig. 2. highlights the SARS-CoV-2 RT-PCR testing procedure: (A) Collection of sample and deposition of viral particles in transport medium. (B) Detergent/chaotropic reagents or heating is used to inactivate the virus. (C) Separation or extraction of RNA is done. In (D) and (E) steps show transfer to PCR-plate in which cDNA synthesis by RT and detection by qPCR happen. The (F) and $(\mathrm{G})$ routes are the direct approaches in which samples are deposited in the transport medium, viral particles are attenuated either through heating or by direct lysis in the detergent-holding buffer. The attenuated samples are then used for the downstream RT-PCR diagnostic reaction. On this theory of molecular detection (reproduced with permission from reference (41)), numerous POC kits and devices operate. 


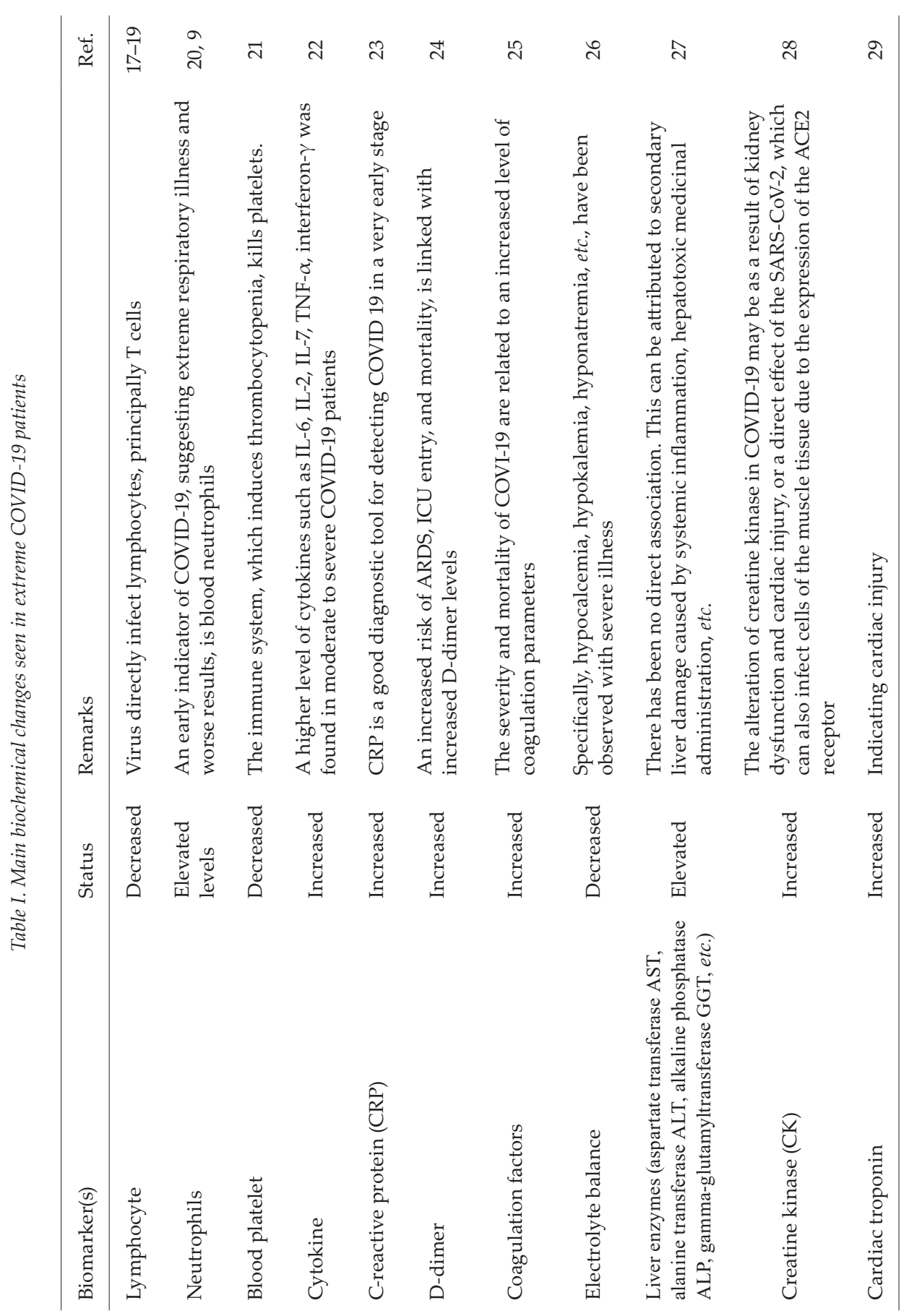




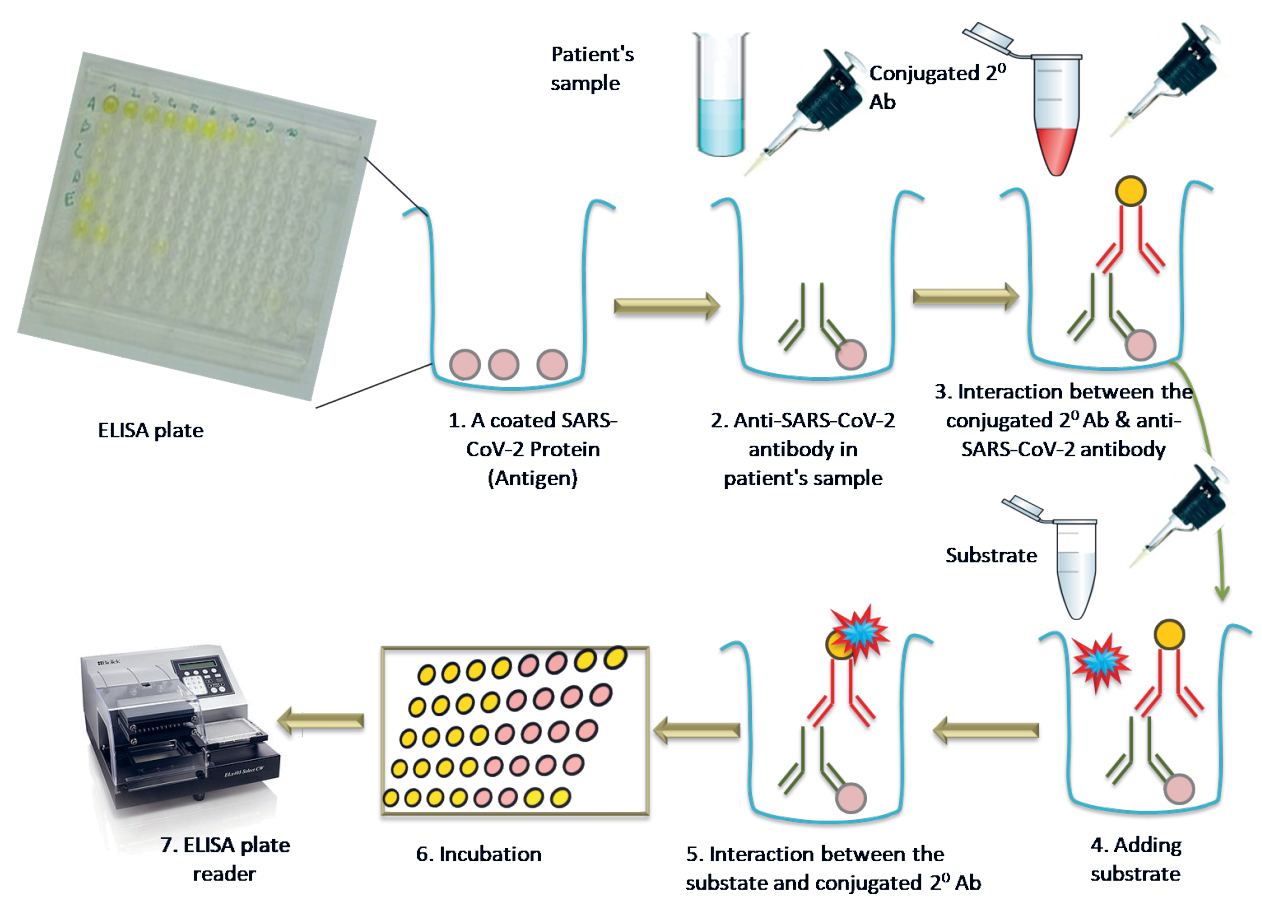

Fig. 3. Various steps of the ELISA technique (reproduced with permission from ref. 46).

\section{Molecular tests (RT-PCR)}

The swabs are placed through nasal and or oral routes into the upper airways for the collection of samples. For mechanically ventilated patients, samples are collected through expectorated phlegm and bronchoalveolar lavage from the lower airways. In order to detect the pathogen's genetic content, the sample was amplified in the $4{ }^{\circ} \mathrm{C}$ annealing stage using a reverse transcription process. To allow the formation of a double-stranded DNA molecule,

Table II. Different target genes to diagnose the COVID-19 worldwide

\begin{tabular}{llll}
\hline $\begin{array}{l}\text { Country/ } \\
\text { organization }\end{array}$ & Target gene/s & Country/organization & Target gene/s \\
\hline CDC USA & Three targets in the N gene & NIH, Thailand & N gene \\
China & ORF1ab and N gene & Hong Kong & ORF1b-nsp14 and N gene \\
Germany & RdRP, E and N gene & NIID, Japan & Spike protein \\
France & Two regions of the RdRP gene & PHA, Canada & RdRp, E and Any3 gene \\
\hline
\end{tabular}

CDC - Centers for Disease Control and Prevention, NIH - National Institute of Health, NIID - National Institute of Infectious Diseases, PHA - Pulmonary Hypertension Association 
a reverse transcription method or a real-time RT-PCR technique can be used from a single-stranded viral RNA molecule $(34,35)$. Finally, replication of genetic information is used to identify the SARS-CoV-2 genetic code. For the molecular level identification of the COVID-19 pathogen, various countries have introduced different target genes (Table II) $(36,37)$.

The sensitivity of these measures is moderate; for example, 53.3 percent of COVID-19 documented patients had positive oropharyngeal swab test, whereas 71 percent of patients had positive sputum test $(38,39)$. After $2-8$ days of viral infection, the outcomes of RT-PCR generally show positivity (40).

\section{Serology based diagnosis}

When molecular techniques deliver an unsatisfactory result, serological tests come into place by detecting antibodies in the patient's blood (42). At the beginning of a novel coronavirus outbreak, serological techniques were considered a supplementary diagnostic method (43). There are several serological measures widely used in laboratories around the world to diagnose novel coronavirus infections (44).

The enzyme-linked immunosorbent assay (ELISA) is widely used to identify a variety of viruses, such as novel coronaviruses (45). The various phases of the novel SARS-CoV-2 ELISA experiment are represented in Fig. 3 (46). The degree of sensitivity of this examination to IgG or IgM in COVID-19 positive patients is almost 84.3 percent (47).

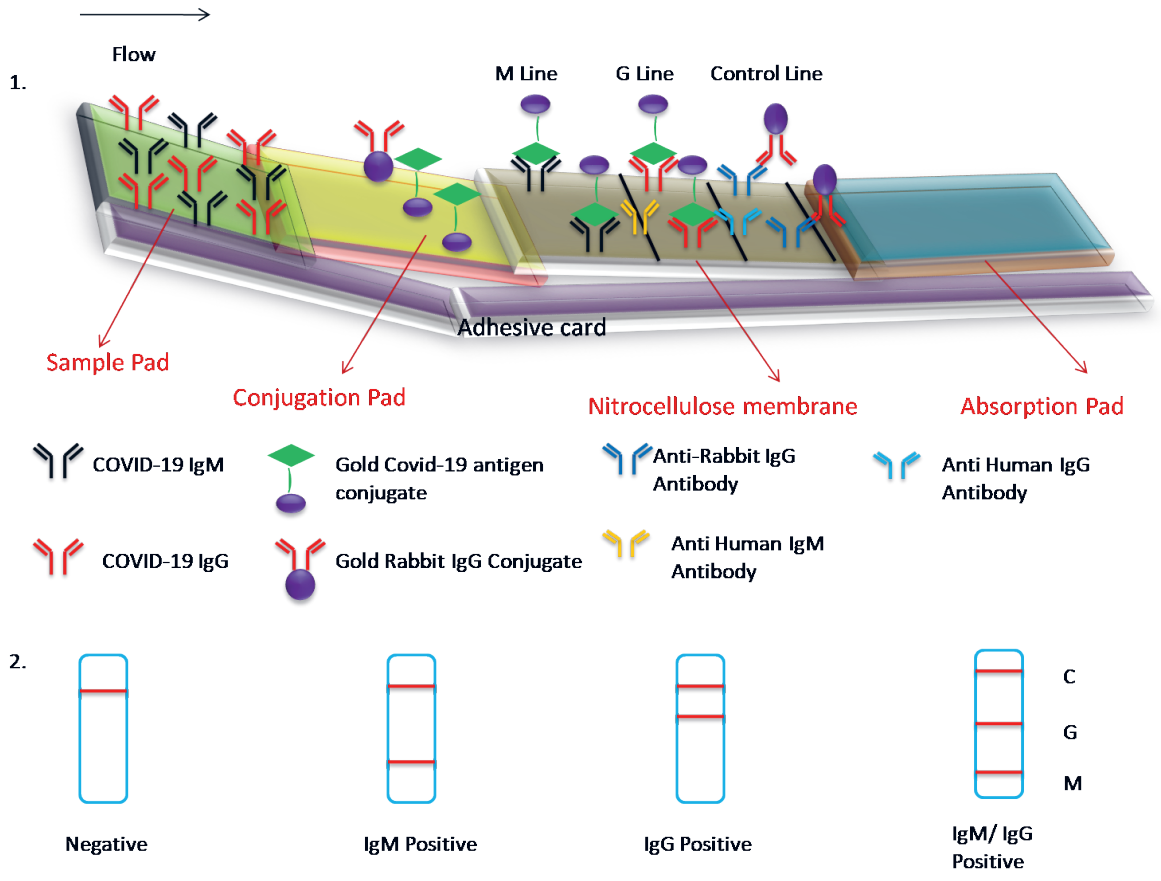

Fig. 4. Steps in lateral flow immunoassay (LFIA)-based COVID-19 diagnosis (reproduced with permission from ref. 50). 
For the identification of novel coronavirus, a tweaked form of luminescent ELISA is used in the chemiluminescent immunoassay (CLIA). Chemiluminescent immunoassay is used to determine the quantity of antibodies such as IgG, IgM, and IgA (48). Patient samples may be mixed with virus-specific proteins using this process. The development of the antigen-antibody complex is then observed by the attachment of another secondary antibody, which undergoes a particular chemical reaction to create illumination. The sum of light released is then measured for the calculation of the number of antibodies found in the COVID-19 sample (44). The degree of sensitivity of CLIA is almost $97.8 \%$ in the COVID-19 positive patients (47).

In Point of Care (POC) immunodiagnostics, rapid diagnostic tests (RDTs) are gaining popularity due to their compact, simple, and portable nature $(44,49)$. RDTs utilize the lateral flow immunoassay (LFIA) technique which uses colour lines to assess if samples of saliva, nasal swabs, and/or blood for viruses are positive or negative (Fig. 4) (50).

Two distinct lines are present in a lateral flow immunoassay where a membrane containing gold-nanoparticle-labeled antibodies $(\mathrm{Au}-\mathrm{Ab})$ and trap antibodies are present (44). As the sample of the patient is placed on the membrane, it moves across the membrane by capillary motion. The viral antigens bind and shape a complex with Au-Ab. This complex then moves forward and is caught by the capture antibodies in the second line, resulting in the formation of coloured lines on the surface, verifying the tests $(44,50)$.

\section{Diagnosis based on radiology}

Chest X-ray. - Chest x-rays normally do not display noticeable alterations in the early stages of the illness. When the infection develops, bilateral multifocal alveolar opacities are discovered, and pleural effusion is often seen in the latter stages (51).

Computed tomography. - High-resolution computed tomography (HRCT) is particularly sensitive and, also in the early stages of the illness, is the preferable technique for COVID-19 pneumonia diagnosis. The most prominent attributes are multifocal bilateral 'ground-glass' areas consistent with convergence and patchy peripheral distribution, with the lower lobes becoming more involved. In certain patients, a 'reverse halo sign' is also seen, which is known as a focal region of patchy opacities surrounded by a consolidation peripheral ring. Other observations include pleural effusion, calcification, cavitation, and lymphadenopathy (52).

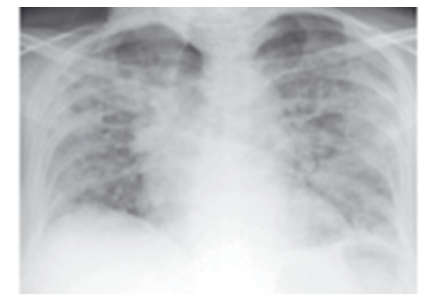

a)

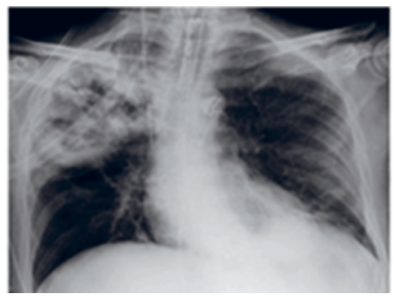

b)

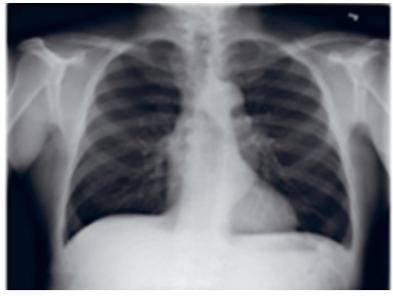

c)

Fig. 5. a) The COVID-19 infected chest, b) pneumonia infected chest, c) normal chest (reproduced with permission from ref. 51). 


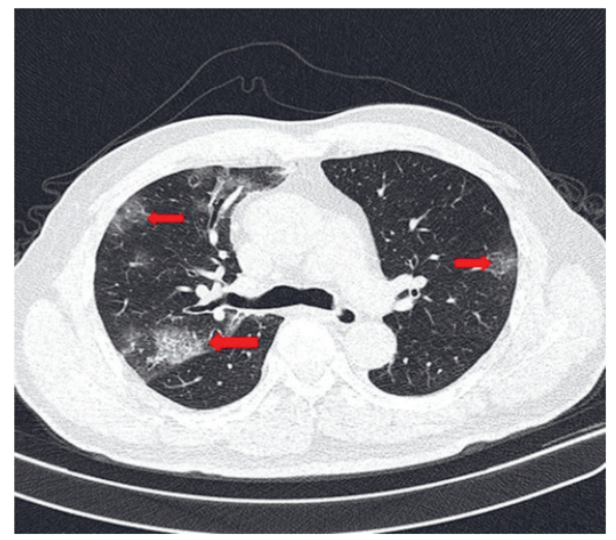

Fig. 6. The inter-lobular septal thickening, multiple ground-glass opacities, and an insane pattern in the two lung lobes (reproduced with permission from ref. 52), comparisons were illustrated in the HRCT scan.

\section{Diagnosis through histopathological changes}

Usually, microscopic findings have low sensitivity and are associated with individuals who are less symptomatic or not symptomatic (44). The post mortem findings of an elderly COVID-19 patient revealed a variety of lung complications, including inflammation in the lungs, pneumocyte hyperplasia, ground-glass opacities in chest x-rays, and lymphocytic focal inflammation, among others (53). These features were close to those identified with previously reported SARS and MERS infections $(54,55)$. Lung consolidation, pleurisy, pericarditis, and pulmonary edema in the affected lung are some of the most noticeable macro-findings (44). In comparison to normal healthy lungs, COVID-19 patients' lungs had an elevated weight (56).

\section{Newer techniques}

CRISPR in the diagnosis of SARS-CoV-2. - The coronavirus preventive antiviral CRISPR, which is a Cas 13-based process, was created as a therapeutic tool, but drug authorities around the world are yet to sanction human clinical trials. The CRISPR-based DETECTR assay offers positive and negative COVID-19 outcomes with 95 and 100 percent accurate predictions, respectively (57).

Algorithm-based coronavirus detection. - An algorithmic technique that focuses on random access instead of batch-wise testing for easy diagnosis of the disease is Hologic Panther Fusion (PF) screening $(58,59)$. Some Iranian experts are recommending one of the techniques to diagnose and provide appropriate care for children suffering from COVID-19 $(44,60)$. Following the analysis of patient symptoms, their response to treatments, and surveillance data obtained from their country, this technique was devised and in use in many countries (44). When comparing PF assay with Laboratory Developed Test (LTD), PF was $98.3 \%$ in agreement with LTD (61). 
LAMP-based detection of SARS-CoV-2. - The technique utilizes the spectrophotometric method to detect the virus. This technique was found to be equally sensitive to the existing RT-qPCR molecular screenings for viral identification (62). Jinzhao Song recommended that the LAMP technique could be improved by combining two stages of amplification in a single tube utilizing recombinase polymerase amplification (RPA) (63). He further recommended using the LAMP to build a POC testing system for user-friendly diagnosis. On combining with paper-based technology, these devices had remarkable features in their ability to be tagged with an advanced cellphone on which quarantined and self-isolated individuals can obtain highly responsive, accurate, and rapid results on their own (64). The findings of paper-based tests may be uploaded to the cloud internet and made accessible to physicians for immediate updates about an individual's health condition, as well as forwarded to the government (65). As a result, rushing to the hospital for a checkup is reduced, and the risks of spreading the virus are significantly decreased (66). When combined with surveillance data, tests that measure the potential of antibody responses to novel coronavirus infection are critical for the production of vaccines and contribute to the estimation of the number of patients that should be screened for a suspected infection (67). The existing scenario necessitates the implementation of lessons gained through the previous coronavirus outbreak in order to address the latest COVID-19 pandemic with a more systematic approach $(44,68)$.

\section{THERAPEUTIC STRATEGIES}

When the COVID-19 pandemic ramifications become evident, pharmaceutical companies immediately seek to either develop new drugs or repurpose medications to manage this menace. A host of effective drug development projects is ongoing in Europe, America, China, and other parts of the world. Pharmaceutical firms such as GlaxoSmithKline, Pfizer, Sanofi, Moderna, AstraZeneca, and Gilead Sciences are designing the majority of treatment options, keeping in mind the various aspects of the disease. The Gilead remdesivir clinical trial, which was performed in partnership with the Chinese Authority, produced mixed results; however, another clinical trial data showed the drug's potential to decrease hospitalization stay and mortality of the COVID-19 patients (69).

The following strategies have been developed so far to contain COVID-19 infection: $(i)$ virus-neutralizing agents, (ii) ACE2-receptor blockers, (iii) TMPRSS2 inhibitor, (iv) NRP-1 inhibitor, $(v)$ cytokines release inhibitors, (vi) protease inhibitors, (vii) RNA-dependent RNA polymerase inhibitor, (viii) use of antibiotics, (ix) use of antimalarial drugs, $(x)$ miscellaneous agents.

The strategies that successfully fight the virus are shown in Fig. 7. A brief overview of the widely discussed drugs has been separately outlined and all the available drugs and therapeutics that can be used in the different conditions and stages of novel SARS-CoV-2 infection have been listed in Table III.

Mild symptomatic COVID-19 patients, suspected or confirmed cases (with light fever, fatigue without dyspnoea), should be excluded in quarantine and palliative care is recommended (71). Fever is usually treated with paracetamol or anti-inflammatory non-steroidal medicines, and no additional medication is recommended at this stage (71). In addition, the use of conventional Chinese medicine to control patient conditions is also encouraged 

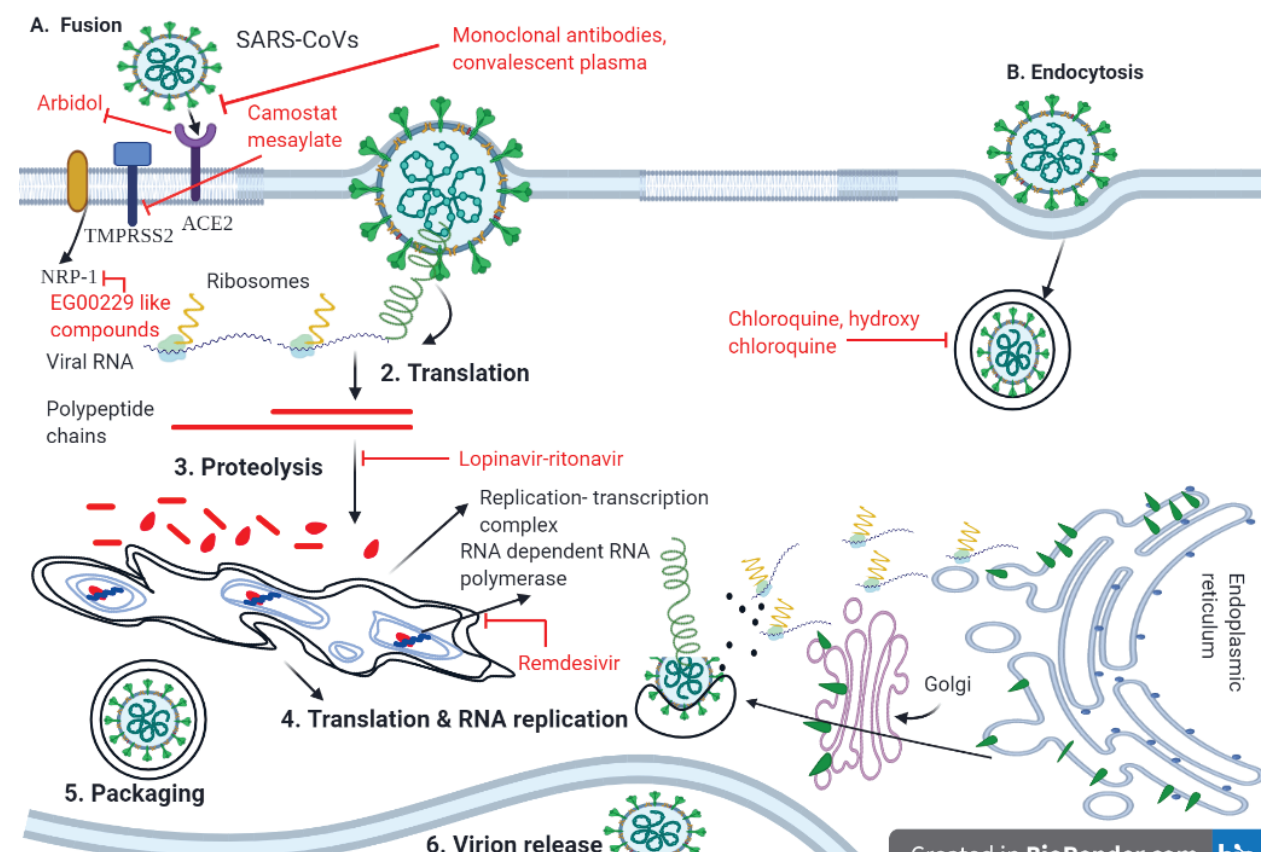

Fig. 7. The figure highlights different strategies to contain the SARS-COV-2 infection (reproduce with permission from ref. 70).

by Chinese health professionals and doctors (72). However, the use of hydroxychloroquine (HCQ) was endorsed by European guidelines in patients with documented COVID-19 (73). In the other severe cases such as COVID-19 pneumonia, COVID-19 ARDS, and septic shock the health caregivers are advised to follow the treatment strategies recommended by the WHO (71).

\section{Therapeutics in use/consideration}

RNA-dependent, RNA polymerase inhibitor: Remdesivir. - Remdesivir, produced by Gilead Sciences, a US-based corporation, has traditionally been used to eradicate the Ebola virus (103). The drug is widely being used in the USA and globally against COVID-19 infection (104). The latest study of hospitalized patients specifically shows a dramatically decreased mortality risk (from 11 to $7.1 \%$ ) with the usage of remdesivir (105).

Protease inhibitors: Lopinavir/ritonavir. - Many clinical trial reports concluded that the treatment with Lopinavir/ritonavir were inconsistent for severely ill COVID-19 patient (78). In addition, a team of Chinese scientists (ChiCTR2000029308) undertook an open-label randomized control study of serious COVID-19 patients seeking treatment with lopinavir/ ritonavir and compared the results with standard care. Their results revealed that there was no therapeutic benefit from lopinavir/ritonavir. In the less severe cases of COVID-19, the possibility of beneficial effects lopinavir/ritonavir is yet to be ascertained (78). 


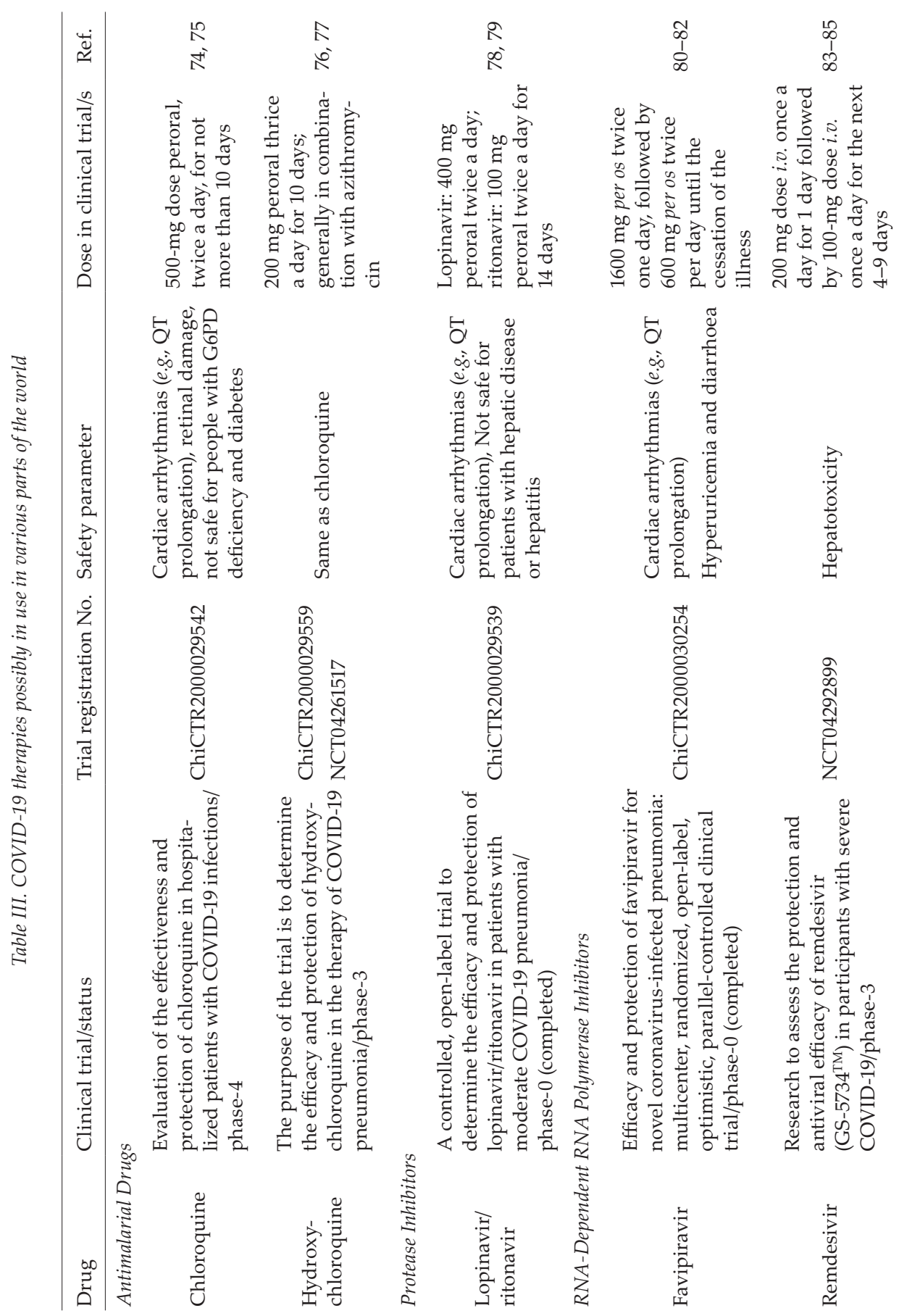




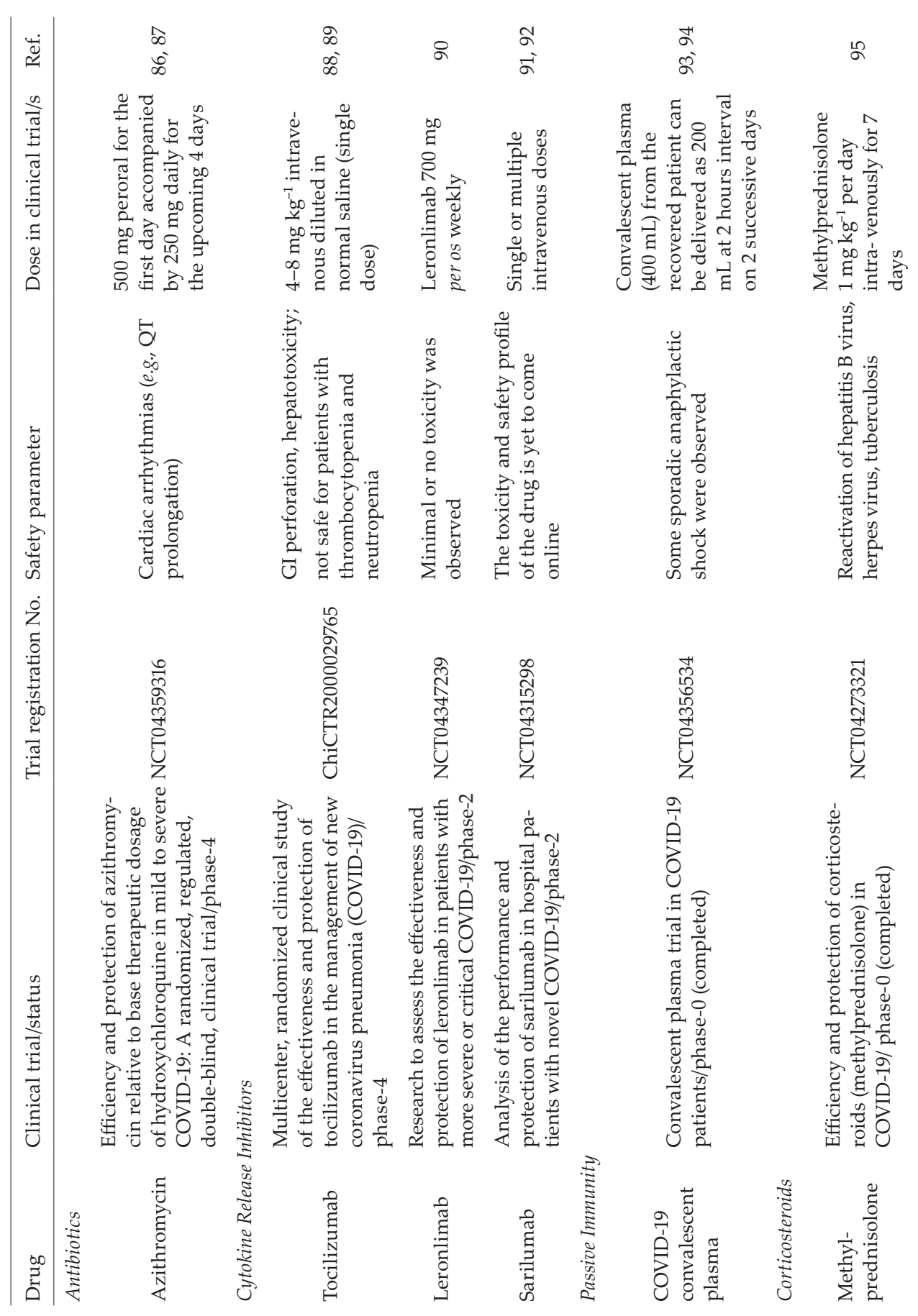




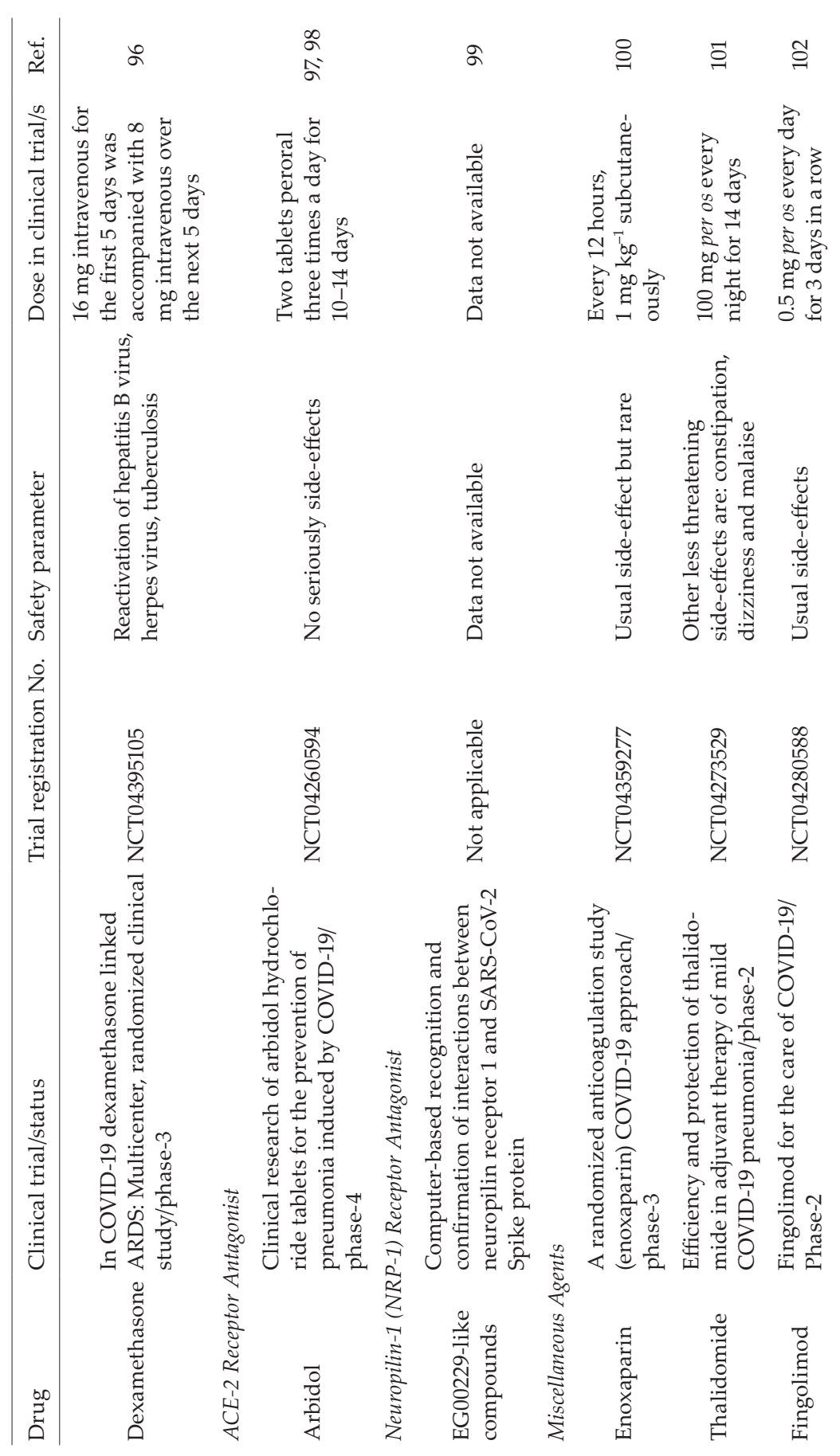


TMPRSS2 blocker: Camostat mesylate. - Camostat mesylate is a powerful protease inhibitor. Previously, the medication was used for a number of therapeutic purposes, including flu and pancreatic inflammatory disorders. The drug also causes the breakdown of the TMPRSS2 co-receptor and therefore, blocks the virus entry into host cells. The serine protease TMPRSS2 interacts with the novel coronavirus spike (S) enzyme to cause the virus to reach the host cell (106). There are no clinical trial reports for this intriguing medication against novel coronavirus infection.

ACE2-Inhibitor: Arbidol (umifenovir). - It is suspected that arbidol (umifenovir) prevents endocytosis of SARS-CoV-2 inside the host cell. Arbidol is reportedly involved in multiple clinical trials against COVID-19 for this cause (107). Along with the NIH, the Chinese clinical research organisations are both running efficacy studies on arbidol, either alone or in conjunction with the protease inhibitor favipiravir (NCT04260594, ChiCTR2000030254).

Human recombinant soluble ACE2: APN01. - Parenteral administration of human recombinant soluble ACE2 binds with the SARS-CoV-2 spike protein, results in suppression of cellular endocy tosis (108). This will, in fact, cause a marked decline in damage to lung cells.

A human recombinant ACE2 (APN01) was engineered and shown to contribute to a substantial reduction in AN-II-mediated lung injury and IL-6 levels based on these positive results. The evidence was adequate to justify a clinical trial with RhACE2. Apeiron Biologics is also sponsoring clinical research on the effectiveness and protection of APN01, currently in phase II (NCT04335136).

\section{Adjuvant therapy}

Anticoagulant therapy. - Endothelial disturbance during the novel coronavirus infection induces thromboembolism, which is a rare and lethal complication in critically ill patients. Multiple reports showed that anticoagulants perform well in reducing serious complications in critically ill COVID-19 patients $(25,109)$.

Vitamin C supplementation. - In 2019, Fowler et al. focused on the usage of vitamin C vs. placebo in ARDS septic patients, and they found that any inflammatory markers or organ failure score did not boost the vitamin C infusion (110). Many current clinical studies confirm the effects of vitamin C in the treatment of COVID-19 (NCT04682574, NCT04335084).

\section{Anecdotal treatment}

Hydroxychloroquine. - Antimalarial medication hydroxychloroquine has demonstrated substantial effectiveness, including HIV-1, Type A, and Type B influenza efficacy. Its antiviral effect on SARS-CoV-2 is based on the effective blockage of viral penetration by obstructing the glycosylation of the ACE-2 receptor (111). It has also been shown that alkalinization of the organelle prevents the development of mature endosomes that shield the virus from immune cells and replication (112). Even though many clinical trials were conducted, the findings were not promising. So far the drug is no more in clinical use.

Ivermectin. - Antiviral behavior was also demonstrated by this wide spectrum antiparasitic agent. It was speculated that the antiviral activity of ivermectin against COVID-19 was achieved from importin-a/b12 obstruction (113). The drug displayed effectiveness in 
an improvement in dyspnea and oxygen saturation and a reduction in time of recovery was observed (NCT04668469).

Teicoplanin. - This glycopeptide antibiotic has demonstrated antiviral properties against Ebola, MERS, SARS, and HIV-1. Teicoplanin is known to interact with endosome development by alkalization. S-protein breaking by cathepsin in the late endosome is blocked, which in turn inhibits viral RNA from being released out of the cells (114). Baron et al. demonstrated that the cathepsin L sequence is also found in the S-protein of novel SARS-CoV-2 and, therefore, causes the virus to enter the cells. It was also reported that in the event of early detection of novel coronavirus disease 19, teicoplanin is probably a good choice of treatment (115).

Humanized monoclonal antibodies: Tocilizumab, bevacizumab, sarilumab. - Monoclonal antibodies (mAbs) normally modify the host organism's immune system response, i.e. a drop in plasma IL-6 levels, which is frequently higher in severe cases of SARS-CoV-2 patients (116). Table III presents the status of tocilizumab, bevacizumab, and sarilumab. However, to decrease the cytokine storm, health care providers around the world often use these drugs.

Interferon- $\alpha$. - Interferon-alpha (INF- $\alpha$ ) has been proven to be effective in containing SARS-CoV-1, it is predicted that INF- $\alpha$ may control the SARS-CoV-2 also, as both the strains are structurally similar. A clinical trial (ChiCTR2000029387) was performed to affirm the effectiveness of INF-alpha against SARS-CoV-2, together with ribavirin, and the findings were disappointing (117).

Zongji Hospital has funded a clinical trial registered with the NIH to determine the efficacy of INF-5-0072 $\beta$ (NCT04293887) and is currently in early phase I (118).

Corticosteroids. - The use of corticosteroid treatment to recover and/or shorten the duration of hospitalisation for COVID-19 patients has traditionally been problematic owing to lack of clinical evidence (119). However, some trials have suggested its effectiveness, which has prompted NIH to establish recommendations for the use and dosing of dexamethasone in COVID-19 patients. However, these recommendations suggested starting steroids in COVID-19 patients with extra oxygen and artificial ventilation in the novel coronavirus (120).

Passive immunity/convalescent plasma. - Recently, a randomized clinical trial was performed to determine the effects of convalescent plasma in severely ill COVID-19 patients and findings indicated little or no benefits. In addition, the length of the illness did not seem to be reduced by its addition to the normal treatment of COVID-19 (121). There are, however, dangers involved with the administration of immunoglobulins, which is why it can only be used with serious or life-threatening COVID-19, according to the FDA Advisory Board (122).

\section{Vaccines: The most sought after therapeutic}

What makes the novel coronavirus so infectious? The answer is simple; this is a new virus, and there is no protection mechanism in our bodies against that virus. Taking precautionary steps and the usage of vaccination are the two most successful methods of alleviating the spread of a pandemic. More notably, the vaccine should be needed to eradicate the high spread capability of COVID-19, which, if not managed, would continue to drive the current pandemic. The most commonly selected target for the development of the COVID-19 


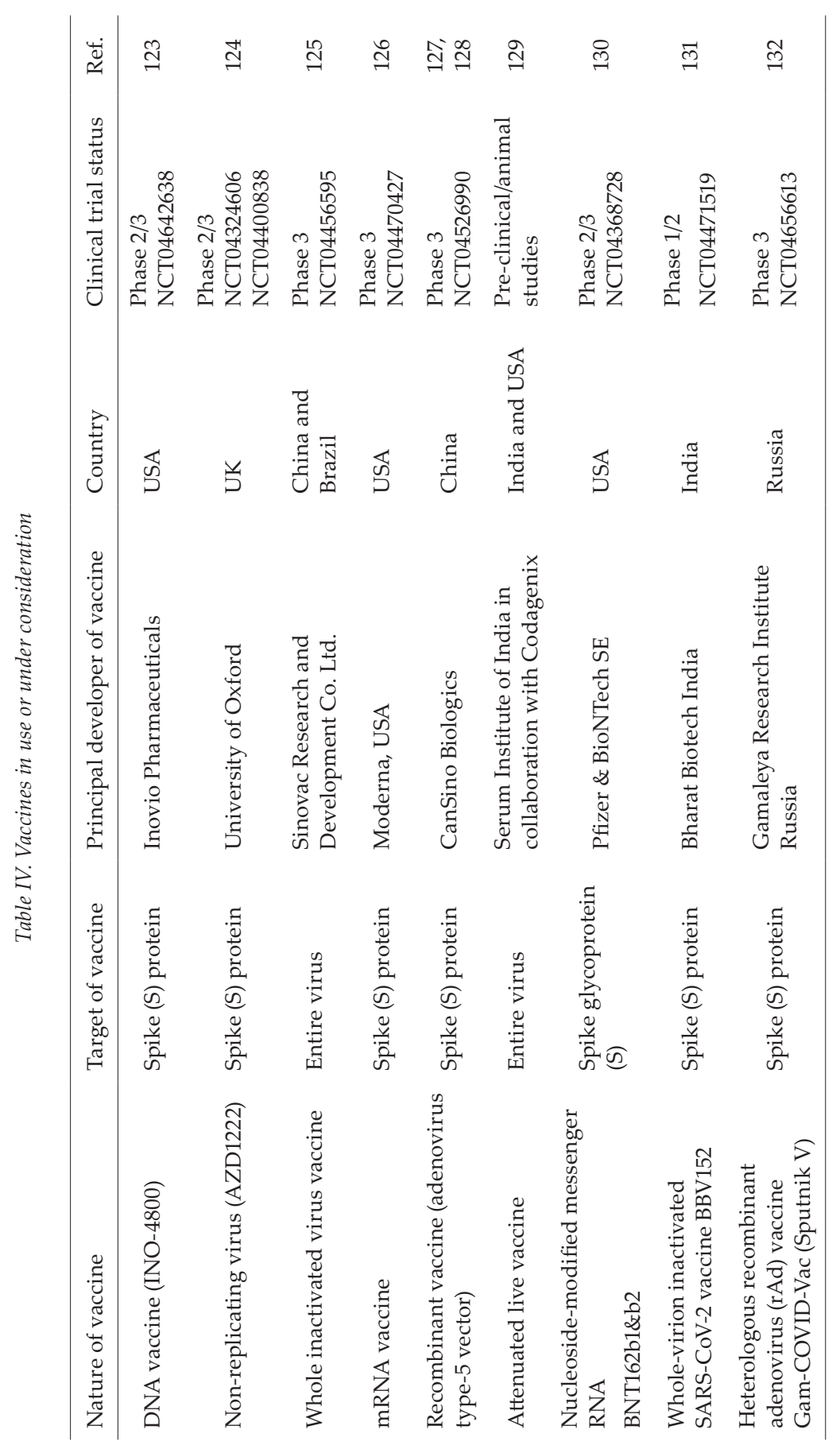


vaccine is the spike (S) protein embedded in the SARS-CoV-2 envelope. Different platforms are actively focusing on the creation of COVID-19 vaccines. Globally, significant COVID-19 vaccines in clinical use or different stages of the clinical trial are listed in Table IV.

There are some side-effects reported since the vaccination program started. The researchers are in the opinion that these are minor hiccups. The benefits of taking vaccines outweigh the devastation of the ongoing pandemic. Moreover, the side-effects of these vaccines were not properly documented; therefore, the author did not incorporate the sporadic reports. The author firmly believes that the vaccines will contribute much to the prevention of the disease.

\section{WHAT FUTURE HOLDS?}

As of February 2021, treatment for COVID-19 depends on the case's severity. In milder conditions, it is enough to rest at home and take medication to relieve fever. The most severe cases require hospital admission, with therapeutic management that might consist of oxygen supplementation, assisted ventilation, and a complete course of therapeutics. Battling SARS-CoV-2 and the infection it causes is of top importance in health research and therapeutic development. A growing number of research organizations are battling to minimize the effects of the disease and to avoid further spreading of COVID-19 infection. Several organizations, including all big and small pharmaceutical industries, are working on different classes of vaccines. Reports of many vaccines have been published in the most reputed journals and are accessible to everyone. Some undesirable effects, not reported in the published data, were observed in many countries during the vaccination programs. The propensity and infectivity of COVID-19 have been lessened in many parts of the world; however, the USA is still facing the heat and peak of the infection. Getting life back to normal is still a distant dream.

\section{EXECUTIVE SUMMARY}

The epidemic of COVID-19 spread quickly through China and engulfed all of the countries across the globe. Several advances have been made in understanding the novel coronavirus's physicochemical properties, the discovery of antiviral drugs and vaccines.

This article highlights our understanding of the novel coronavirus's symptoms in brief, pathogenesis, diagnostics, and therapeutic strategies to contain COVID-19. SARS-COV-2 emerged from bats and is likely to enter some unknown intermediate hosts; binding to high-affinity ACE2 receptors inevitably infects humans. The clinical findings including serological, radiological, and other advanced diagnostic strategies contributed much to control the disease. Supporting procedures in conjunction with powerful antiviral drugs such as remdesivir, lopinavir/ritonavir, or corticosteroids have thus far been used with a degree of confidence in the care of COVID-19 patients. However, in several areas of the world, vaccination initiatives took place; the vaccines' safety and efficacy to control the outbreak is yet to be identified. This review concludes that improved therapies and diagnostics for COVID-19 must continually be explored as new variants are constantly emerging.

\section{REFERENCES}

1. H. Zhu, L. Wei and P. Niu, The novel coronavirus outbreak in Wuhan, China, Glob. Health Res. Pol. 5 (2020) Article ID 6 (3 pages); https://doi.org/10.1186/s41256-020-00135-6 
2. F. Di Gennaro, D. Pizzol, C. Marotta, M. Antunes, V. Racalbuto, N. Veronese and L. Smith, Coronavirus diseases (COVID-19) current status and future perspectives: a narrative review, Int. J. Environ. Res. Public Health 17 (2020) Article ID 2690 (11 pages); https://doi.org/10.3390/ijerph17082690

3. WHO, Coronavirus (COVID-19) Dashboard; https://covid19.who.int/?adgroupsurvey=\{adgroupsurve y\}\&gclid=CjwKCAjwxuuCBhATEiwAIIIz0fTN6oKYMvVIaWv1taX_3SpdYTW6ohBt1aIMc3M9MV MC7cjEx9RKOBoClzYQAvD_BwE; last access date March 24, 2021

4. S. Payne, Viruses - From Understanding to Investigation, Family Coronaviridae, Academic Press, London, 2017, Chapter 17, pp. 149-158; https://doi.org/10.1016/B978-0-12-803109-4.00017-9

5. H. Li, Y. M. Wang, J. Y. Xu and B. Cao, Potential antiviral therapeutics for 2019 novel coronavirus, ZhonghuaJie he hehu xi zazhi (Chinese J. Tuberculosis and Respiratory Diseases) 43 (2020) 170-172; https://doi.org/10.3760/cma.j.issn.1001-0939.2020.03.004

6. Thermo Fisher Scientific, Solutions For Surveillance of the S Gene Mutation in the B.1.1.7 (501Y.V1) SARS-Cov-2 Strain Lineage; https://www.thermofisher.com/blog/behindthebench/solutions-for-surveillance-of-the-s-gene-mutation-in-the-b117-501yv1-sars-cov-2-strain-lineage/?cid=gsd_cbu_sbu_ r03_co_cp1422_pjt6968_gsd00000_0se_gaw_ta_lgn_em-b117-corona\&gclid=Cj0KCQiAj9iBBhCJAR IsAE9qRtD-1DLjg_C NjrMy2w1c0szCMR1d0FEOaF_Vn4VZlsOJIq0w2Mf95UaAqPJEALw_wcB; last access date February 17, 2021

7. L. L. Ren, Y. M. Wang, Z. Q. Wu, Z. C. Xiang, L. Guo, T. Xu, Y. Z. Jiang, Y. Xiong, Y. J. Li, X.W. Li and $\mathrm{H}$. Li, Identification of a novel coronavirus causing severe pneumonia in human: a descriptive study, Chin. Med. J. 133 (2020) 1015-1024; https://doi.org/10.1097/CM9.0000000000000722

8. C. Huang, Y. Wang, X. Li, L. Ren, J. Zhao, Y. Hu, L. Zhang, G. Fan, J. Xu, X. Gu and Z. Cheng, Clinical features of patients infected with 2019 novel coronavirus in Wuhan, China, Lancet 395 (2020) 497-506; https://doi.org/10.1016/S0140-6736(20)30183-5

9. Y. H. Jin, L. Cai, Z. S. Cheng, H. Cheng, T. Deng, Y. P. Fan, C. Fang, D. Huang, L. Q. Huang, Q. Huang, Y. Han, B. Hu, F. Hu, B. H. Li, Y. R. Li, K. Liang, L.K. Lin, L. S. Luo, J. Ma, L. L. Ma, Z. Y. Peng, Y. B. Pan, Z. Y. Pan, X. Q. Ren, H. M. Sun, Y. Wang, Y. Y. Wang, H. Weng, C. J. Wei, D. F. Wu, J. Xia, Y. Xiong, H. B. Xu, X. M. Yao, Y. F. Yuan, T. S. Ye, X. C. Zhang, Y. W. Zhang, Y. G. Zhang, H. M. Zhang, Y. Zhao, M. J. Zhao, H. Zi, X. T. Zeng, Y. Y. Wang and X. H. Wang, A rapid advice guideline for the diagnosis and treatment of 2019 novel coronavirus (2019-nCoV) infected pneumonia (standard version), Mil. Med. Res. 7 (2020) Article ID 4 (23 pages); https://doi.org/10.1186/s40779-020-0233-6

10. C. Chakraborty, A. R. Sharma, G. Sharma, M. Bhattacharya and S. S. Lee, SARS-CoV-2 causing pneumonia-associated respiratory disorder (COVID-19): diagnostic and proposed therapeutic options, Eur. Rev. Med. Pharmacol. 24 (2020) 4016-4026; https://doi.org/10.26355/eurrev_202004_20871

11. W. Wang, J. Tang and F. Wei, Updated understanding of the outbreak of 2019 novel coronavirus (2019-nCoV) in Wuhan, China, J. Med. Virol. 92 (2020) 441-447; https://doi.org/10.1002/jmv.25689

12. T. Klopfenstein, H. Zahra, Q. Lepiller, P. Y. Royer, L. Toko, V. Gendrin and S. Zayet, New loss of smell and taste: Uncommon symptoms in COVID-19 patients in Nord Franche-Comte cluster, France, Int. J. Infect. Dis. 100 (2020) 117-122; https://doi.org/10.1016/j.ijid.2020.08.012

13. M. Suzuki, K. Saito, W. P. Min, C. Vladau, K. Toida, H. Itoh and S. Murakami, Identification of viruses in patients with post-viral olfactory dysfunction, Laryngoscope 117 (2007) 272-277; https://doi. org/10.1097/01.mlg.0000249922.37381.1e

14. D. Harmer, M. Gilbert, R. Borman and K. L. Clark, Quantitative mRNA expression profiling of ACE 2, a novel homologue of angiotensin converting enzyme, FEBS Lett. 532 (2002) 107-110; https://doi. org/10.1016/s0014-5793(02)03640-2

15. M. Letko, A. Marzi and V. Munster, Functional assessment of cell entry and receptor usage for SARS-CoV-2 and other lineage B betacoronaviruses, Nat. Microbiol. 5 (2020) 562-569; https://doi. org/10.1038/s41564-020-0688-y

16. L. Cantuti-Castelvetri, R. Ojha, L. D. Pedro, M. Djannatian, J. Franz, S. Kuivanen, F. van der Meer, K. Kallio, T. Kaya, M. Anastasina and T. Smura, Neuropilin-1 facilitates SARS-CoV-2 cell entry and infectivity, Science 370 (2020) 856-860; https://doi.org/10.1126/science.abd2985 
17. Y. Wu, C. Guo, L. Tang, Z. Hong, J. Zhou, X. Dong, H. Yin, Q. Xiao, Y. Tang, X. Qu and L. Kuang, Prolonged presence of SARS-CoV-2 viral RNA in faecal samples, Lancet Gastroenterol. Hepatol. 5 (2020) 434-435; https://doi.org/10.1016/S2468-1253(20)30083-2

18. S. Tavakolpour, T. Rakhshandehroo, E. X. Wei and M. Rashidian, Lymphopenia during the COVID-19 infection: What it shows and what can be learned, Immunol. Lett. 225 (2020) 31-32; https://doi. org/10.1016/j.imlet.2020.06.013

19. N. Chen, M. Zhou, X. Dong, J. Qu, F. Gong, Y. Han, Y. Qiu, J. Wang, Y. Liu, Y. Wei and T. Yu, Epidemiological and clinical characteristics of 99 cases of 2019 novel coronavirus pneumonia in Wuhan, China: a descriptive study, Lancet 395 (2020) 507-513; https://doi.org/10.1016/S0140-6736(20)30211-7

20. R. H. Du, L. R. Liang, C. Q. Yang, W. Wang, T. Z. Cao, M. Li, G. Y. Guo, J. Du, C. L. Zheng, Q. Zhu, M. Hu, X. Y. Li, P. Peng and H. Z. Shi, Predictors of mortality for patients with COVID-19 pneumonia caused by SARS-CoV-2: a prospective cohort study, Eur. Respir. J. 55 (2020) Article ID 2000524 (8 pages); https://doi.org/10.1183/13993003.00524-2020

21. P. Xu, Q. Zhou and J. Xu, Mechanism of thrombocytopenia in COVID-19 patients, Ann. Hematol. 99 (2020) 1205-1207; https://doi.org/10.1007/s00277-020-04019-0

22. V. J. Costela-Ruiz, R. Illescas-Montes, J. M. Puerta-Puerta, C. Ruiz and L. Melguizo-Rodríguez, SARS-CoV-2 infection: the role of cytokines in COVID-19 disease, Cytokine Growth Factor Rev. 54 (2020) 62-75; https://doi.org/10.1016/j.cytogfr.2020.06.001

23. C. Tan, Y. Huang, F. Shi, K. Tan, Q. Ma, Y. Chen, X. Jiang and X. Li, C-reactive protein correlates with computed tomographic findings and predict severe COVID-19 early, J. Med. Virol. 92 (2020) 856-862; https://doi.org/10.1002/jmv.25871

24. B. Yu, X. Li, J. Chen, M. Ouyang, H. Zhang, X. Zhao, L. Tang, Q. Luo, M. Xu, L. Yang and G. Huang, Evaluation of variation in D-dimer levels among COVID-19 and bacterial pneumonia: a retrospective analysis, J. Thromb. Thrombolysis 50 (2020) 548-557; https://doi.org/10.1007/s11239-020-02171-y

25. N. Tang, H. Bai, X. Chen, J. Gong, D. Li and Z. Sun, Anticoagulant treatment is associated with decreased mortality in severe coronavirus disease 2019 patients with coagulopathy, J. Thromb. Haemost. 18 (2020) 1094-1099; https://doi.org/10.1111/jth.14817

26. G. Lippi, A. M. South and B. M. Henry, Electrolyte imbalances in patients with severe coronavirus disease2019(COVID-19), Ann.Clin.Biochem.57(2020)262-265;https://doi.org/10.1177/0004563220922255

27. P. Kumar, M. Sharma, A. Kulkarni and P. N. Rao, Pathogenesis of liver injury in coronavirus disease 2019, J. Clin. Exp. Hepatol. 10 (2020) 641-642; https://doi.org/10.1016/j.jceh.2020.05.006

28. G. Lippi and M. Plebani, The critical role of laboratory medicine during coronavirus disease 2019 (COVID-19) and other viral outbreaks, Clin. Chem. Lab. Med. 58 (2020) 1063-1069; https://doi. org/10.1515/cclm-2020-0240

29. Y. Sandoval, J. L. Januzzi Jr. and A. S. Jaffe, Cardiac troponin for the diagnosis and risk-stratification of myocardial injury in COVID-19: JACC review topic of the week, J. Am. Coll. Cardiol. 76 (2020) 1244-1258; https://doi.org/10.1016/j.jacc.2020.06.068

30. J. F. W. Chan, C. C. Y. Yip, K. K. W. To, T. H. C. Tang, S. C. Y. W, K. H. Leung, A. Y. F. Fung, A. C. K. Ng, Z. Zou, H. W. Tsoi, G. K. Y. Choi, A. R. Tam, V. C. C. Cheng, K. H. Chan, O. T. Y. Tsang and K. Y. Yuen, Improved molecular diagnosisof COVID-19 by the novel, highly sensitive and specific COVID-19-RdRp/Hel Real-time reverse transcription-PCR assay validatedin vitro and with clinical specimens, J. Clin. Microbiol. 58 (2020) e00310-20 (10 pages); https://doi.org/10.1128/JCM.00310-20

31. S. P. Adhikari, S. Meng, Y. J. Wu, Y. P. Mao, R. X. Ye, Q. Z. Wang, C. Sun, S. Sylvia, S. Rozelle, H. Raat and $\mathrm{H}$. Zhou, Epidemiology, causes, clinical manifestation and diagnosis, prevention and control of coronavirus disease (COVID-19) during the early outbreak period: a scoping review, Infect. Dis. Pov. 9 (2020) Article ID 29 (12 pages); https://doi.org/10.1186/s40249-020-00646-x

32. B. A. Forbes, D. Sahm and A. Weissfeld, Study Guide for Bailey and Scott's Diagnostic Microbiology, $12^{\text {th }}$ ed., Mosby Elsevier, St. Louis (MO) 2007 pp. 118-119. 
33. C. G. Huang, K. M. Lee, M. J. Hsiao, S. L. Yang, P. N. Huang, Y. N. Gong, T. H. Hsieh, P. W. Huang, Y. J. Lin, Y. C. Liu, K. C. Tsao and S. R. Shih, Culture-based virus isolation to evaluate potential infectivity of clinical specimens tested for COVID-19, J. Clin. Microbiol. 58 (2020) e01068-20 (8 pages); https://doi.org/10.1128/JCM.01068-20

34. S. Bhadra, Y. S. Jiang, M. R. Kumar, R. F. Johnson, L. E. Hensley and A. D. Ellington, Real-time sequence-validated loop-mediated isothermal amplification assays for detection of Middle East respiratory syndrome coronavirus (MERS-CoV), PLoS One 10 (2015) e0123126 (21 pages); https://doi. org/10.1371/journal.pone.0123126

35. J. F. Chan, G. K. Choi, A. K. Tsang, K. M. Tee, H. Y. Lam, C. C. Yip, K. K. To, V. C. Cheng, M. L. Yeung, S. K. Lau, P. C. Woo, K. H. Chan, B. S. F. Tang and K. Y. Yuen, Development and evaluation of novel real-time reverse transcription-PCR assays with locked nucleic acid probes targeting leader sequences of human-pathogenic Coronaviruses, J. Clin. Microbiol. 53 (2015) 2722-2726; https://doi. org/10.1128/JCM.01224-15

36. WHO, Coronavirus Disease (COVID-19) Technical Guidance: Laboratory Testing for 2019-NCOV in Humans; https://www.who.int/docs/defaultsource/coronaviruse/whoinhouseassays.pdf?sfvrsn= de3a76aa_2; last access date February 10, 2021

37. J. J. LeBlanc, J. B. Gubbay, Y. Li, R. Needle, S. R. Arneson, D. Marcino, H. Charest, G. Desnoyers, K. Dust, R. Fattouh, R. Garceau, G. German, T. F Hatchette, R. A. Kozak, M. Krajden, T. Kuschak, A. L. S. Lang, P. Levett, T. Mazzulli, R. McDonald, S. Mubareka, N. Prystajecky, C. Rutherford, M. Smieja, Y. Yu, G. Zahariadis, N. Zelyas and N. Bastien, Real-time PCR-based SARS-CoV-2 detection in Canadian laboratories, J. Clin. Virol. 128 (2020) Article ID 104433 (5 pages); https://doi.org/10.1016/j. jcv.2020.104433

38. W. Zhang, R. H. Du, B. Li, X. S. Zheng, X. L. Yang, B. Hu, Y. Y. Wang, G. F. Xiao, B. Yan, Z. L. Shi and P. Zhou, Molecular and serological investigation of 2019-nCoV infected patients: implication of multiple shedding routes, Emerg. Microbes. Infect. 9 (2020) 386-389; https://doi.org/10.1080/22221751. 2020.1729071

39. Y. Fang, H. Zhang, J. Xie, M. Lin, L. Ying, P. Pang and W. Ji, Sensitivity of chest CT for COVID-19: comparison to RT-PCR, Radiology 296 (2020) 115-117; https://doi.org/10.1148/radiol.2020200432

40. P. Huang, T. Liu, L. Huang, H. Liu, M. Lei, W. Xu, X. Hu, J. Chen and B. Liu, Use of chest CT in combination with negative RT-PCR assay for the 2019 novel coronavirus but high clinical suspicion, Radiology 295 (2020) 22-23; https://doi.org/10.1148/radiol.2020200330

41. I. Smyrlaki, M. Ekman, A. Lentini, N. R. de Sousa, N. Papanicolaou, M. Vondracek, J. Aarum, H. Safari, S. Muradrasoli, A. G. Rothfuchs, J. Albert, B. Högberg and B. Reinius, Massive and rapid COVID-19 testing is feasible by extraction-free SARS-CoV-2 RT-PCR, Nat. Commun. 11 (2020) Article ID 4812 (12 pages); https://doi.org/10.1038/s41467-020-18611-5

42. T. G. Ksiazek, D. Erdman, C. S. Goldsmith, S. R. Zaki, T. Peret, S. Emery, S. Tong, C. Urbani, J. A. Comer, W. Lim, P. E. Rollin and S. F. Dowell, A novel coronavirus associated with severe acute respiratory syndrome, N. Engl. J. Med. 348 (2003) 1953-1966; https://doi.org/10.1056/NEJMoa030781

43. J. S. M. Peiris, S. T. Lai, L. L. Poon, Y. Guan, L. Y. Yam, W. Lim, J. Nicholls, W. K. Yee, W. W. Yan, M. T. Cheung, V. C. Cheng, K. H. Chan, D. N. C. Tsang, R. W. H. Yung, T. K. Ng and K. Y. Yuen, Coronavirus as a possible cause of severe acute respiratory syndrome, Lancet 361 (2003) 1319-1325; https:// doi.org/10.1016/S0140-6736(03)13077-2

44. P. Asrani, M. S. Eapen, C. Chia, G. Haug, H. C. Weber, M. I. Hassan and S. S. Sohal, Diagnostic approaches in COVID-19: clinical updates, Expert Rev. Resp. Med. 15 (2021) 197-212; https://doi.org/1 0.1080/17476348.2021.1823833

45. M. A. MacMullan, A. Ibrayeva, K. Trettner, L. Deming, S. Das, F. Tran, J. R. Moreno, J. G. Casian, P. Chellamuthu, J. Kraft, K. Kozak, F. E. Turner, V. I. Slepnev and L. M. Le Page, ELISA detection of SARS-CoV-2 antibodies in saliva, Sci. Rep. 10 (2020) Article ID 20818 (8 pages); https://doi.org/10.1038/ s41598-020-775554 
46. A. E. Dhamad and M. A. Rhida, COVID-19: molecular and serological detection methods, Peer J. 8 (2020) e10180 (18 pages); https://doi.org/10.7717/peerj.10180

47. M. L. Bastos, G. Tavaziva, S. K. Abidi, J. R. Campbell, L. P. Haraoui, J. C. Johnston, Z. Lan, S. Law, E. MacLean, A. Trajman, D. Menzies, A. Benedetti and F. A. Khan, Diagnostic accuracy of serological tests for covid-19: systematic review and meta-analysis, BMJ 370 (2020) Article ID m2516 (13 pages); https://doi.org/10.1136/bmj.m2516

48. X. F. Cai, J. Chen, J. L. Hu, Q. X. Long, H. J. Deng, P. Liu, K. Fan, P. Liao, B. Z. Liu, G. C. Wu, Y. K. Chen, Z. J. Li, K. Wang, X. L. Zhang, W. G. Tian, J. L. Xiang, H. X. Du, J. Wang, Y. Hu, N. Tang, Y. Lin, J. H. Ren, L. Y. Huang, J. Wei, C. Y. Gan, Y. M. Chen, Q. Z. Gao, A. M. Chen, C. L. He, D. X. Wang, P. Hu, F. C. Zhou, A. L. Huang and D. Q. Wang, A peptide-based magnetic chemiluminescence enzyme immunoassay for serological diagnosis of coronavirus disease 2019, J. Infect. Dis. 222 (2020) 189-193; https://doi.org/10.1093/infdis/jiaa243

49. A. Olalekan, B. Iwalokun, O. M. Akinloye, O. Popoola, T. A. Samuel and O. Akinloye, COVID-19 rapid diagnostic test could contain transmission in low-and middle-income countries, Afr. J. Lab. Med. 9 (2020) Article ID 1255 (8 pages); https://doi.org/10.4102/ajlm.v9i1.1255

50. Z. Li, Y. Yi, X. Luo, N. Xiong, Y. Liu, S. Li, R. Sun, Y. Wang, B. Hu, W. Chen, Y. Zhang, J. Wang, B. Huang, Y. Lin, J. Yang, W. Cai, X. Wang, J. Cheng, Z. Chen, K. Sun, W. Pan, Z. Zhan, L. Chen, and F. Ye, Development and clinical application of a rapid IgM-IgG combined antibody test for SARSCoV-2 infection diagnosis, J. Med. Vir. 92 (2020) 1518-1524; https://doi.org/10.1002/jmv.25727

51. T. B. Chandra, K. Verma, B. K. Singh, D. Jain and S. S. Netam, Coronavirus disease (COVID-19) detection in chest X-ray images using majority voting based classifier ensemble, Exp. Syst. Appl. 165 (2021) Article ID 113909 (13 pages); https://doi.org/10.1016/j.eswa.2020.113909

52. W. C. Dai, H. W. Zhang, J. Yu, H. J. Xu, H. Chen, S. P. Luo, H. Zhang, L. H. Liang, X. L. Wu, Y. Lei and F. Lin, CT imaging and differential diagnosis of COVID-19, Can. Assoc. Radiol. J. 71 (2020) 195200; https://doi.org/10.1177/0846537120913033

53. S. Tian, W. Hu, L. Niu, H. Liu, H. Xu and S. Y. Xiao, Pulmonary pathology of early phase 2019 novel coronavirus (COVID-19) pneumonia in two patients with lung cancer, J. Thorac. Oncol. 15 (2020) 700-704; https://doi.org/10.1016/j.jtho.2020.02.010

54. Y. Ding, H. Wang, H. Shen, Z. Li, J. Geng, H. Han, J. Cai, X. Li, W. Kang, D. Weng, Y. Lu, D. Wu, L. He and K. Yao, The clinical pathology of severe acute respiratory syndrome (SARS): a report from China, J. Pathol. 200 (2003) 282-289; https://doi.org/10.1002/path.1440

55. D. L. Ng, F. Al Hosani, M. K. Keating, S. I. Gerber, T. L. Jones, M. G. Metcalfe, S. Tong, Y. Tao, N. N. Alami, L. M. Haynes, M. A. Mutei, L. A. Wareth, T. M. Uyeki, D. L. Swerdlow, M. Barakat and S. R. Zaki, Clinicopathologic, immunohistochemical, and ultrastructural findings of a fatal case of Middle East respiratory syndrome coronavirus infection in the United Arab Emirates, Am. J. Pathol. 186 (2016) 652-658; https://doi.org/10.1016/j.ajpath.2015.10.024

56. B. Hanley, S. B. Lucas, E. Youd, B. Swift and M. Osborn, Autopsy in suspected COVID-19 cases, J. Clin. Pathol. 73 (2020) 239-242; http://dx.doi.org/10.1136/jclinpath-2020-206522

57. J. P. Broughton, X. Deng, G. Yu, C. L. Fasching, V. Servellita, J. Singh, X. Miao, J. A. Streithorst, A. Granados, A. S. Gonzalez, K. Zorn, A. Gopez, E. Hsu, W. Gu, S. Miller, C. Y. Pan, H. Guevara, D. A. Wadford, J. S. Chen and C. Y. Chiu, CRISPR-Cas12-based detection of SARS-CoV-2, Nat. Biotechnol. 38 (2020) 870-874; https://doi.org/10.1038/s41587-020-0513-4

58. T. Ganzenmueller, R. Kaiser, C. Baier, M. Wehrhane, B. Hilfrich, J. Witthuhn, S. Flucht and A. Heim, Comparison of the performance of the panther fusion respiratory virus panel to R-gene and laboratory developed tests for diagnostic and hygiene screening specimens from the upper and lower respiratory tract, J. Med. Microbiol. 69 (2020) 427-435; https://doi.org/10.1099/jmm.0.001133

59. S. M. Novak-Weekley, E. M. Marlowe, M. Poulter, D. Dwyer, D. Speers, W. Rawlinson, C. Baleriola and C. C. Robinson, Evaluation of the Cepheid Xpert flu assay for rapid identification and differen- 
tiation of influenza A, influenza A 2009 H1N1, and influenza B viruses, J. Clin. Microbiol. 50 (2012) 1704-1710; https://doi.org/10.1128/JCM.06520-11

60. A. Karimi, S. R. Tabatabaei, M. Rajabnejad, Z. Pourmoghaddas, H. Rahimi, S. Armin, R. M. Ghanaie, M. R. Kadivar, S. A. Fahimzad, I. Sedighi, B. Mirrahimi, A. S. Dashti, N. Bilan, S. A. Oskouyi, H. Barekati and M. Khalili, An algorithmic approach to diagnosis and treatment of coronavirus disease 2019 (COVID-19) in children: Iranian expert's consensus statement, Arch. Pediatr. Infect. Dis. 8 (2020) e102400 (6 pages); https://doi.org/10.5812/pedinfect.102400

61. C. A. Hogan, M. K. Sahoo, C. Huang, N. Garamani, B. Stevens, J. Zehnder and B. A. Pinsky, Comparison of the Panther Fusion and a laboratory-developed test targeting the envelope gene for detection of SARS-CoV-2, J. Clin. Virol. 127 (2020) Article ID 104383 (3 pages); https://doi.org/10.1016/j. jcv.2020.104383

62. Y. Zhang, N. Odiwuor, J. Xiong, L. Sun, R. O. Nyaruaba, H. Wei and N. A. Tanner, Rapid molecular detection of SARS-CoV-2 (COVID-19) virus RNA using colorimetric LAMP, medRxiv (preprint), posted Feb 29, 2020; https://doi.org/10.1101/2020.02.26.20028373

63. M. El-Tholoth, H. H. Bau and J. Song, A single and two-stage, closed-tube, molecular test for the 2019 Novel Coronavirus (COVID-19) at home, clinic, and points of entry, ChemRxiv (preprint) posted Feb 19, 2020; https://doi.org/10.26434/chemrxiv.11860137.v1

64. S. J. Lo, S. C. Yang, D. J. Yao, J. H. Chen, W. C. Tu and C. M. Cheng, Molecular-level dengue fever diagnostic devices made out of paper, Lab. Chip. 13 (2013) 2686-2692; https://doi.org/10.1039/ C3LC50135C

65. T. Yang, Y. C. Wang, C. F. Shen and C. M. Cheng, Point-of-care RNA-based diagnostic device for COVID-19, Diagnostics (Basel) 10 (2020) Article ID 165 (3 pages); https://doi.org/10.3390/diagnostics10030165

66. F. Song, N. Shi, F. Shan, Z. Zhang, J. Shen, H. Lu, Y. Ling, Y. Jiang and Y. Shi, Emerging 2019 novel coronavirus (2019-nCoV) pneumonia, Radiology 295 (2020) 210-217; https://doi.org/10.1148/radiol.2020200274

67. WHO, Advice on the Use of Point-of-Care Immunodiagnostic Tests for COVID-19: Scientific Brief; https:// www.who.int/news-room/commentaries/detail/advice-on-the-use-of-point-of-care-immunodiagnostic-tests-for-covid-19; last access date February 5, 2021

68. X. Marchand-Senécal, R. Kozak, S. Mubareka, N. Salt, J. B. Gubbay, A. Eshaghi, V. Allen, Y. Li, N. Bastien, M. Gilmour, O. Ozaldin and J. A. Leis, Diagnosis and management of first case of COVID-19 in Canada: lessons applied from SARS, Clin. Infect. Dis. 71 (2020) 2207-2210; https://doi.org/10.1093/ cid/ciaa227

69. A. Piscoya, L. F. Ng-Sueng, A. P. del Riego, R. C. Viacava, V. Pasupuleti, Y. M. Roman, P. Thota, C. M. White and A. V. Hernandez, Efficacy and harms of remdesivir for the treatment of COVID-19: A systematic review and meta-analysis, PloS ONE 15 (2020) e0243705 (19 pages); https://doi.org/10.1371/ journal.pone. 0243705

70. K. Kupferschmidt and J. Cohen, Race to find COVID-19 treatments accelerate, Science 367 (2020) 1412-1413; https://doi.org/10.1126/science.367.6485.1412

71. WHO, COVID-19 Clinical Management; file://C:/Users/LENOVO/Downloads/WHO-2019-nCoV-clinical-2021.1-eng.pdf; last access date March 30, 2021

72. WHO, Traditional Chinese Medicine Could Make "Health for One" True; https://www.who.int/intellectualproperty/studies/Jia.pdf; last access date March 30, 2021

73. The COVID-19 RISK and Treatments (CORIST) Collaboration, Use of hydroxychloroquine in hospitalised COVID-19 patients is associated with reduced mortality: Findings from the observational multicentre Italian CORIST study, Eur. J. Intern. Med. 82 (2020) 38-47; https://doi.org/10.1016/j. ejim.2020.08.019 
74. M. Gendrot, E. Javelle, E. Le Dault, A. Clerc, H. Savini and B. Pradines, Chloroquine as prophylactic agent against COVID-19, Int. J. Antimicrob. Agents 55 (2020) Article ID 105980 (2 pages); https://doi. org/10.1016/j.ijantimicag.2020.105980

75. Chinese Clinical Trial Register (ChiCTR), Study for the efficacy of chloroquine in patients with novel coronavirus pneumonia (COVID-19); http://www.chictr.org.cn/showprojen.aspx?proj=48968; last access date February 15, 2021

76. P. Gautret, J. C. Lagier, P. Parola, V. T. Hoang, L. Meddeb, M. Mailhe, B. Doudier, J. Courjon, V. Giordanengo, V. E. Vieira, H. T. Dupont, S. Honoré, P. Colson, E. Chabrière, B. La Scola, J. M. Rolain, P. Brouqui and D. Raoult, Hydroxychloroquine and azithromycin as a treatment of COVID-19: results of an open-label non-randomized clinical trial, Int. J. Antimicrob. Agents 56 (2020) Article ID 105949 (6 pages); https://doi.org/10.1016/j.ijantimicag.2020.105949

77. NIH, Efficacy and Safety of Hydroxychloroquine for Treatment of Pneumonia Caused by 2019-nCoV (HC$n \mathrm{CoV}) ;$ http://clinicaltrials.gov/ct2/show/NCT04261517; last access date January 19, 2021

78. B. Cao, Y. Wang, D. Wen, W. Liu, J. Wang, G. Fan, L. Ruan, B. Song, Y. Cai, M. Wei, X. Li and J. Xia, A trial of lopinavir-ritonavir in adults hospitalized with severe COVID-19, N. Engl. J. Med. 382 (2020) 1787-1799; https://doi.org/10.1056/NEJMoa2001282

79. Chinese Clinical Trial Register (ChiCTR), A Randomized, Open-Label Study to Evaluate the Efficacy and Safety of Lopinavir-Ritonavir in Patients with Mild Novel Coronavirus Pneumonia (COVID-19); http:// www.chictr.org.cn/show projen.aspx?proj=48684; last access date February 21, 2021

80. NIH, Favipiravir Combined with Tocilizumab in the Treatment of Corona Virus Disease 2019; https://clinicaltrials.gov/ct2/show/NCT04310228; last access date February 21, 2021

81. K. Shiraki and T. Daikouku, Favipiravir, an anti-influenza drug against life-threatening RNA virus infections, Pharmacol. Ther. 209 (2020) Article ID 107512 (15 pages); https://doi.org/10.1016/j.pharmthera.2020.107512

82. Chinese Clinical Trial Register (ChiCTR), The Efficacy and Safety of Favipiravir for Novel CoronavirusInfected Pneumonia: A Multicenter, Randomized, Open, Positive, Parallel-Controlled Clinical Study; http:// www.chictr.org.cn/show projen.aspx?proj=50137; last access date February 21, 2021

83. Y. Wang, D. Zhang, G. Du, R. Du, J. Zhao, Y. Jin, S. Fu, L. Gao, Z. Cheng, Q. Lu, Y. Hu, G. Luo, K. Wang, Y. Lu, H. Li, S. Wang, S. Ruan, C. Yang, C. Mei, Y. Wang, D. Ding, F. Wu, X. Tang, X. Ye, Y. Ye, B. Liu, J. Yang, W. Yin, A. Wang, G. Fan, F. Zhou, Z. Liu, X. Gu, J. Xu, L. Shang, Y. Zhang, L. Cao, T. Guo, Y. Wan, H. Qin, Y. Jiang, T. Jaki, F. G Hayden, P. W. Horby, B. Cao and C. Wang, Remdesivir in adults with severe COVID-19: a randomised, double-blind, placebo-controlled, multicenter trial, Lancet 395 (2020) 1569-1578; https://doi.org/10.1016/S0140-6736(20)31022-9

84. C. J. Gordon, E. P. Tchesnokov, J. Y. Feng, D. P. Porter and M. Götte, The antiviral compound remdesivir potently inhibits RNA-dependent RNA polymerase from Middle East respiratory syndrome coronavirus, J. Biol. Chem. 295 (2020) 4773-4779; https://doi.org/10.1074/jbc.AC120.013056

85. NIH, Study to Evaluate the Safety and Antiviral Activity of Remdesivir (GS-5734 ${ }^{\mathrm{TM}}$ ) in Participants with Severe Coronavirus Disease (COVID-19); https:/clinicaltrials.gov/ct2/show/NCT04292899; last access date February 20, 2021

86. P. Zarogoulidis, N. Papanas, I. Kioumis, E. Chatzaki, E. Maltezos and K. Zarogoulidis, Macrolides: from in vitro anti-inflammatory and immunomodulatory properties to clinical practice in respiratory disease, Eur. J. Clin. Pharmacol. 68 (2012) 479-503; https://doi.org/10.1007/s00228-011-1161-x

87. NIH, Azithromycin in Hospitalized COVID-19 Patients (AIC); https://clinicaltrials.gov/ct2/show/ NCT04359316; last access date February 21, 2021

88. X. Xu, M. Han, T. Li, W. Sun, D. Wang, B. Fu, Y. Zhou, X. Zheng, Y. Yang, X. Li, X. Zhang, A. Pan and H. Wei, Effective treatment of severe COVID-19 patients with tocilizumab, Proc. Nat. Acad. Sci. USA 117 (2020) 10970-10975; https://doi.org/10.1073/pnas.2005615117 
89. NIH, Tocilizumab for SARS-Cov2 Severe Pneumonitis; http://clinicaltrials.gov/ct2/show/NCT04315480; last access February 24, 2021

90. CytoDyn Inc., Study to Evaluate the Efficacy and Safety of Leronlimab for Patients With Severe or Critical Coronavirus Disease 2019 (COVID-19); https://clinicaltrials.gov/ct2/show/NCT04347239; last access date February 21, 2021

91. NIH, Cohort Multiple Randomized Controlled Trials Open-Label of Immune Modulatory Drugs and Other Treatments in COVID-19 Patients - Sarilumab Trial - CORIMUNO-19-SARI (CORIMUNO-SARI); https://clinicaltrials.gov/ct2/show/NCT04324073; last access date February 20, 2021.

92. NIH, Evaluation of the Efficacy and Safety of Sarilumab in Hospitalized Patients with COVID-19; http:// clinicaltrials.gov/ct2/show/NCT04315298; last access date February 20, 2021.

93. C. Shen, Z. Wang, F. Zhao, Y. Yang, J. Li, J. Yuan, F. Wang, D. Li, M. Yang, L. Xing, J. Wei, H. Xiao, Y. Yang, J. Qu, L. Qing, L. Chen, Z. Xu, L. Peng, Y. Li, H. Zheng, F. Chen, K. Huang, Y. Jiang, D. Liu, Z. Zhang, Y. Liu and L. Liu, Treatment of 5 critically ill patients with COVID-19 with convalescent plasma, JAMA 323 (2020) 1582-1589; https://doi.org/10.1001/jama.2020.4783

94. Royal College of Surgeons in Ireland - Medical University of Bahrain, Convalescent Plasma Trial in COVID -19 Patients; https://clinicaltrials.gov/ct2/show/NCT04356534; last access date February 25, 2021.

95. NIH, Efficacy and Safety of Corticosteroids in COVID-19 (Methylprednisolone); https://clinicaltrials.gov/ ct2/show/NCT04273321; last access date February 25, 2021.

96. NIH, Dexamethasone for COVID-19 Related ARDS: a Multicenter Randomized Clinical Trial; https://clinicaltrials.gov/ct2/show/NCT04395105; last access date February 21, 2021.

97. NIH, Clinical Study of Arbidol Hydrochloride Tablets in the Treatment of Pneumonia Caused by Novel Coronavirus; https://clinicaltrials.gov/ct2/show/NCT04260594; last access date February 21, 2021.

98. M. Nojomi, Z. Yassin, H. Keyvani, M. J. Makiani, M. Roham, A. Laali, N. Dehghan, M. Navaei and M. Ranjbar, Effect of arbidol (umifenovir) on COVID-19: a randomized controlled trial, BMC Infect. Dis. 20 (2020) Article ID 954 (10 pages); https://doi.org/10.1186/s12879-020-05698-w

99. S. Perez-Miller, M. Patek, A. Moutal, C. R. Cabel, C. A. Thorne, S. K. Campos and R. Khanna, In silico identification and validation of inhibitors of the interaction between neuropilin receptor 1 and SARS-CoV-2 Spike protein, bioRxiv (preprint), posted Sept 23, 2020; https://doi. org/10.1101/2020.09.22.308783

100. NIH, A Randomized Trial of Anticoagulation Strategies in COVID-19; https://clinicaltrials.gov/ct2/ show/NCT04359277; last access date February 21, 2021.

101. NIH, The Efficacy and Safety of Thalidomide in the Adjuvant Treatment of Moderate New Coronavirus (COVID-19) Pneumonia; http://clinicaltrials.gov/ct2/show/NCT04273529; last access date February 21, 2021.

102. NIH, Fingolimod in COVID-19; http://clinicaltrials.gov/ct2/show/NCT04280588; last access date February 21, 2021.

103. S. Mulangu, L. E. Dodd, R. T. Davey, O. T. Mbaya, M. Proschan, D. Mukadi, M. L. Manzo, D. Nzolo, A. T. Oloma, A. Ibanda, R. Ali and S. Coulibaly, A randomized, controlled trial of Ebola virus disease therapeutics, N. Engl. J. Med. 381 (2019) 2293-2303; https://doi.org/10.1056/NEJMoa1910993

104. NIH, Study to Evaluate the Safety and Antiviral Activity of Remdesivir (GS-5734 ${ }^{\mathrm{TM}}$ ) in Participants with Severe Coronavirus Disease (COVID-19); https://clinicaltrials.gov/ct2/show/NCT04292899; last access date February 21, 2021.

105. J. H. Beigel, K. M. Tomashek, L. E. Dodd, A. K. Mehta, B. S. Zingman, A. C. Kalil, E. Hohmann, H. Y. Chu, A. Luetkemeyer, S. Kline, D. L. de Castilla and R. W. Finberg, Remdesivir for the treatment of Covid-19-final report, New. Engl. J. Med. 383 (2020) 1813-1826; https://doi.org/10.1056/NEJMoa2007764 
106. M. Hoffmann, H. K. Weber, S. Schroeder, N. Krüger, T. Herrler, S. Erichsen, T. S. Schiergens, G. Herrler, N. H. Wu, A. Nitsche, M. A. Müller, C. Drosten and S. Pöhlmann, SARS-CoV-2 cell entry depends on ACE2 and TMPRSS2 and is blocked by a clinically proven protease inhibitor, Cell 181 (2020) 271-280; https://doi.org/10.1016/j.cell.2020.02.052

107.C. Liu, Q. Zhou, Y. Li, L. V. Garner, S. P. Watkins, L. J. Carter, J. Smoot, A. C. Gregg, A. D. Daniels, S. Jervey and D. Albaiu, Research and development on therapeutic agents and vaccines for COVID-19 and related human coronavirus diseases, ACS Cent. Sci. 6 (2020) 315-331; https://doi.org/10.1021/ acscentsci.0c00272

108. K. Kuba, Y. Imai, S. Rao, H. Gao, F. Guo, B. Guan, Y. Huan, P. Yang, Y. Zhang, W. Deng, L. Bao, B. Zhang, G. Liu, Z. Wang, M. Chappell, Y. Liu, D. Zheng, A. Leibbrandt, T. Wada, A. S. Slutsky, D. Liu, C. Qin, C. Jiang, J. M. Penninger, A crucial role of angiotensin converting enzyme 2 (ACE2) in SARS coronavirus-induced lung injury, Nat. Med. 11 (2005) 875-879; https://doi.org/10.1038/nm1267

109. J. Helms, C. Tacquard, F. Severac, I. L. Lorant, M. Ohana, X. Delabranche, H. Merdji, R. C. Jehl, M. Schenck, F. F. Gandet, S. F. Kremer, V. Castelain, F. Schneider, L. Grunebaum, E. A. Cano, L. Sattler, P. M. Mertes and F. Meziani, High risk of thrombosis in patients with severe SARS-CoV-2 infection: a multicenter prospective cohort study, Int. Care Med. 46 (2020) 1089-1098; https://doi.org/10.1007/ s00134-020-06062-x

110. A. A. Fowler, J. D. Truwit, R. D. Hite, P. E. Morris, C. DeWilde, A. Priday, B. Fisher, L. R. Thacker, R. Natarajan, D. F. Brophy, R. Sculthorpe, R. Nanchal, A. Syed, J. Sturgill, G. S. Martin, J. Sevransky, M. Kashiouris, S. Hamman, K. F. Egan, A. Hastings, W. Spencer, S. Tench, O. Mehkri, J. Bindas, A. Duggal, J. Graf, S. Zellner, L. Yanny, C. McPolin, T. Hollrith, D. Kramer, C. Ojielo, T. Damm, E. Cassity, A. Wieliczko and M. Halquist, Effect of vitamin C infusion on organ failure and biomarkers of inflammation and vascular injury in patients with sepsis and severe acute respiratory failure: the CITRIS-ALI randomized clinical trial, JAMA 322 (2019) 1261-1270; https://doi.org/10.1001/ jama.2019.11825

111.A. Savarino, L. D. Trani, I. Donatelli, R. Cauda and A. Cassone, New insights into the antiviral effects of chloroquine, Lancet Infect. Dis. 6 (2006) 67-69; https://doi.org/10.1016/S1473-3099(06)70361-9

112. J. Liu, R. Cao, M. Xu, X. Wang, H. Zhang, H. Hu, Y. Li, Z. Hu, W. Zhong and M. Wang, Hydroxychloroquine, a less toxic derivative of chloroquine, is effective in inhibiting SARS-CoV-2 infection in vitro, Cell Discov. 6 (2020) Article ID 16 (4 pages); https://doi.org/10.1038/s41421-020-0156-0

113. L. Caly, J. D. Druce, M. G. Catton, D. A. Jans and K. M. Wagstaff, The FDA-approved drug ivermectin inhibits the replication of SARS-CoV-2 in vitro, Antivir. Res. 178 (2020) Article ID 104787 (4 pages); https://doi.org/10.1016/j.antiviral.2020.104787

114. N. Zhou, T. Pan, J. Zhang, Q. Li, X. Zhang, C. Bai, F. Huang, T. Peng, J. Zhang, C. Liu, L. Tao and H. Zhang, Glycopeptide antibiotics potently inhibit cathepsin L in the late endosome/lysosome and block the entry of ebola virus, middle east respiratory syndrome coronavirus (MERSCoV), and Severe Acute Respiratory Syndrome Coronavirus (SARS-CoV), J. Biol. Chem. 291 (2016) 92189232; https://doi.org/10.1074/jbc.M116.716100

115. S. A. Baron, C. Devaux, P. Colson, D. Raoult and J. M. Rolain, Teicoplanin: an alternative drug for the treatment of COVID-19, Int. J. Antimicrob. Agents 55 (2020) Article ID 105944 (2 pages); https:// doi.org/10.1016/j.ijantimicag.2020.105944

116. T. Herold, V. Jurinovic, C. Arnreich, B. J. Lipworth, J. C. Hellmuth, M. von Bergwelt-Baildon, M. Klein and T. Weinberger, Elevated levels of IL-6 and CRP predict the need for mechanical ventilation in COVID-19, J. Allergy Clin. Immunol. 146 (2020) 128-136; https://doi.org/10.1016/j.jaci.2020.05.008

117. Chinese Clinical Trial Register (ChiCTR), Comparative effectiveness and safety of ribavirin plus interferon-alpha, lopinavir/ritonavir plus interferon-alpha and ribavirin plus lopinavir/ritonavir plus interferon-alphain in patients with mild to moderate novel coronavirus pneumonia; http:// www.chictr.org.cn/showprojen.aspx?proj=48782; last access date February 21, 2021. 
118. NIH, Efficacy and Safety of IFN-A2 $\beta$ in the Treatment o Novel Coronavirus Patients; https://clinicaltrials. gov/ct2/show/NCT04293887; last access date February 21, 2021.

119.C. D. Russell, J. E. Millar and J. K. Baillie, Clinical evidence does not support corticosteroid treatment for 2019-nCoV lung injury, Lancet 395 (2020) 473-475; https://doi.org/10.1016/S01406736(20)30317-2

120. NIH, COVID-19 Treatment Guidelines; https://www.covid19treatmentguidelines.nih.gov/immunomodulators/corticosteroids/\#: :text=Given \%20the \%20potential \%20benefit \%20of,supplemental \%20oxygen \%20but \%20who \%20are; last access date February 21, 2021.

121. L. Li, W. Zhang, Y. Hu, X. Tong, S. Zheng, J. Yang, Y. Kong, L. Ren, Q. Wei, H. Mei, C. Hu, C. Tao, R. Yang, J. Wang, Y. Yu, Y. Guo, X. Wu, Z. Xu, L. Zeng, N. Xiong, L. Chen, J. Wang, N. Man, Y. Liu, H. Xu, E. Deng, X. Zhang, C. Li, C. Wang, S. Su, L. Zhang, J. Wang, Y. Wu and Z. Liu, Effect of convalescent plasma therapy on time to clinical improvement in patients with severe and lifethreatening COVID-19: a randomized clinical trial, JAMA 324 (2020) 460-470; https://doi. org/10.1001/jama.2020.10044

122. FDA, Recommendations for Investigational COVID-19 Convalescent Plasma; https://www.fda.gov/ vaccines-blood-biologics/investigational-new-drug-ind-or-device-exemption-ide-process-cber/recommendations-investigational-covid-19-convalescent-plasma; last access date February 21, 2021.

123. NIH, Safety, Immunogenicity, and Efficacy of INO-4800 for COVID-19 in Healthy Seronegative Adults at High Risk of SARS-Cov-2 Exposure; https://clinicaltrials.gov/ct2/show/NCT04642638; last access date February 21, 2021.

124. NIH, A Study of a Candidate COVID-19 Vaccine (COV001); https://clinicaltrials.gov/ct2/show/ NCT04324606; last access date February 21, 2021.

125. NIH, Clinical Trial of Efficacy and Safety of Sinovac's Adsorbed COVID-19 (Inactivated) Vaccine in Healthcare Professionals (PROFISCOV); https://clinicaltrials.gov/ct2/show/NCT04456595; last access date February 21, 2021.

126. NIH, A Study to Evaluate Efficacy, Safety, and Immunogenicity of mRNA-1273 Vaccine in Adults Aged 18 Years and Older to Prevent COVID-19; https://clinicaltrials.gov/ct2/show/NCT04470427; last access date February 21, 2021.

127. NIH, Phase III Trial of a COVID-19 Vaccine of Adenovirus Vector in Adults 18 Years Old and Above; https:/clinicaltrials.gov/ct2/show/NCT04526990; last access date February 21, 2021.

128. F. C. Zhu, Y. H. Li, X. H. Guan, L. H. Hou, W. J. Wang, J. X, Li, S. P. Wu, B. S. Wang, Z. Wang, L. Wang, S. Y. Jia, H. D. Jiang, L. Wang, T. Jiang, Y. Hu, J. B. Gou, S. B. Xu, J. J. Xu, X. W. Wang, W. Wang and W. Chen, Safety, tolerability, and immunogenicity of a recombinant adenovirus type-5 vectored COVID-19 vaccine: a dose escalation, open-label, non-randomised, first-in-human trial, Lancet 395 (2020) 1845-1854; https://doi.org/10.1016/S0140-6736(20)31208-3

129. Clinical Trials Arena, Serum Institute of India Brings Covid-19 Vaccine into Animal Testing; https:// www.clinicaltrialsarena.com/news/serum-institute-india-covid-19-vaccine/; last access date February 21, 2021.

130. NIH, Study to Describe the Safety, Tolerability, Immunogenicity, and Efficacy of RNA Vaccine Candidates Against COVID-19 in Healthy Individuals; https://clinicaltrials.gov/ct2/show/NCT04368728; last access date February 21, 2021.

131. NIH, Whole-Virion Inactivated SARS-CoV-2 Vaccine (BBV152) for COVID-19 in Healthy Volunteers (BBV152); https://clinicaltrials.gov/ct2/show/NCT04471519; last access date February 21, 2021.

132. NIH, A Phase III Clinical Trial of the Immunogenicity and Safety of the Gam-COVID-Vac Vaccine Against COVID-19 in the UAE, SPUTNIK-UAE, https://clinicaltrials.gov/ct2/show/NCT04656613; last access date February 21, 2021.

133. Against COVID-19 in the UAE, SPUTNIK-UAE, https://clinicaltrials.gov/ct2/show/NCT04656613; last access date February 21, 2021. 